Kant, M.; Kanda, W.

\title{
Innovation intermediaries: What does it take to survive over time?
}

Journal article | Accepted manuscript (Postprint)

This version is available at https://doi.org/10.14279/depositonce-8542

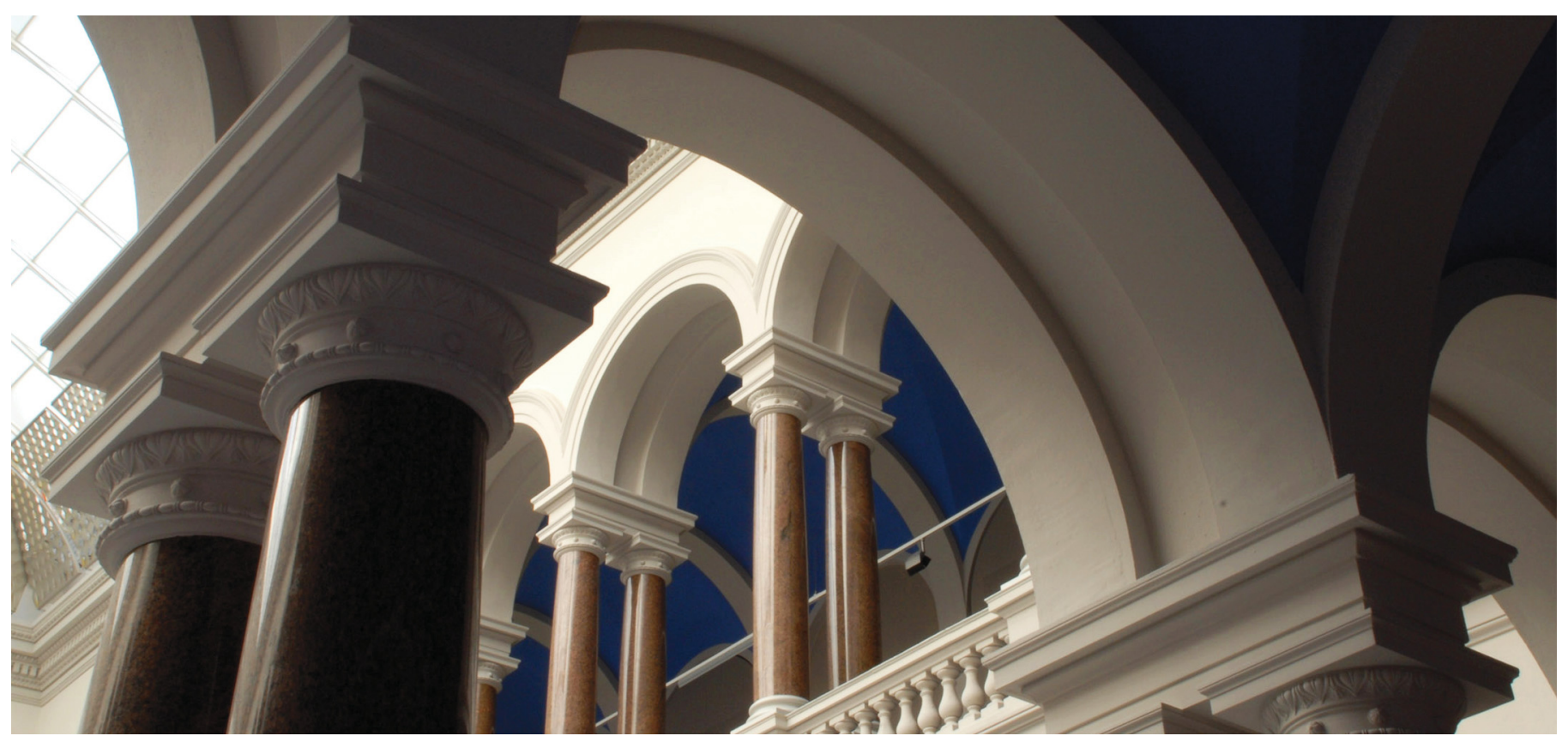

Kant, M., \& Kanda, W. (2019). Innovation intermediaries: What does it take to survive over time? Journal of Cleaner Production, 229, 911-930. https://doi.org/10.1016/j.jclepro.2019.04.213 


\title{
Innovation Intermediaries: what does it take to survive over time? \\ Marvin Kant*, Wisdom Kanda** \\ *Department of Entrepreneurship and Innovation Management, Technische Universität Berlin, Germany; \\ ** Division of Environmental Technology and Management, Linköping University, Sweden
}

\begin{abstract}
Innovation intermediaries are recognised as crucial actors that can facilitate the innovation process, support eco-innovation and contribute to sustainable entrepreneurship. However, little is known about the temporal dimension of innovation intermediaries and how they change over time to survive, which is crucial if intermediaries are to contribute to long term sustainabilityoriented transformations. An in-depth case study design with a comparative approach was chosen to examine four innovation intermediaries at different development stages in the related fields of $\mathrm{CO}_{2}$ utilisation and Carbon Capture Storage technology in Europe, the USA, and Australia. This study sheds light on the survival of innovation intermediaries over time: Firstly, by describing the dynamics in an intermediary's (a) characteristics, (b) scope, (c) objectives, and (d) roles and activities. Secondly, by identifying at least four interrelated factors influencing an intermediary's survival: (i) neutrality, (ii) technological context, (iii) shared consensus, and (iv) internal value creation. Thus, this article contributes to the literature by highlighting the complexity and tensions in the survival of intermediaries through an analysis of both internal and contextual factors, as opposed to previous literature which has mainly focused on how intermediaries change their roles and activities over time to survive.
\end{abstract}

Keywords: sustainable-oriented innovation, sustainable entrepreneurship, $\mathrm{CO}_{2}$ utilisation, CCS, intermediaries

\section{Correspondence:}

**wisdom.kanda@liu.se

\section{Introduction}

Addressing contemporary environmental problems such as climate change, biodiversity loss, and natural resource depletion requires changes to existing socio-technical systems (Geels, 2011). Such changes are systemic and encompass deep structural changes in existing sociotechnical systems for energy, transportation, production and agri-food encompassing their related technologies, policies, markets, consumer and business practices, cultural meanings, and scientific knowledge (Grin et al., 2010). In particular tackling climate change requires urgent decarbonisation of energy supply and demand (Matschoss and Heiskanen, 2017), and production systems (e.g., Bui et al., 2018). Technological change is often argued as a necessity to tackle such contemporary environmental problems albeit not self-sufficient due to the multifaceted nature of these environmental problems (Kanda, 2017). Furthermore, relevant technological innovations take decades to reach mainstream markets due to barriers such as lock-ins to high carbon technologies, path dependencies, and resistance from incumbents. Thus, supporting the innovation and widespread diffusion of technologies to decarbonise energy supply and demand is of keen interest for policy makers and researchers alike (Matschoss and Heiskanen, 2017).

In the quest to decarbonise energy and production systems, a promising technological development relates to technologies that are developed with the intention to capture carbon dioxide $\left(\mathrm{CO}_{2}\right)$ and utilise it for $\mathrm{CO}_{2}$-based products or permanently store it in geological formations. Such technologies particularly $\mathrm{CO}_{2}$ utilisation continue to emerge characterised by 
high capital intensity and radicality compared to alternative technologies (Kant, 2017). And even though these technologies have the potential to convert $\mathrm{CO}_{2}$ into raw material, with some related products such as $\mathrm{CO}_{2}$-based fuels about to reach mainstream markets, there is a continued need for their rapid and widespread diffusion if such technologies are to make a meaningful contribution to sustainability transitions (cf. Boons and Lüdeke-Freund, 2013; Kanda et al., 2016). Technological innovation systems (TIS), a set of networks of actors and institutions that interact in a specific technological field, support the development and diffusion of technologies such as those for $\mathrm{CO}_{2}$ utilisation. A central feature of the TIS approach are system functions (indicators of system performance), which are used to identify system weaknesses and to inform policymakers about actions on how to facilitate the development of a particular technology (Bergek et al., 2008). A TIS is in itself situated in a broader context of "other" actors, networks, institutions and technologies (Bergek et al., 2015). Thus, changes in the context (e.g., changing policies or the emergence complementary technologies) affect and are affected by the focal TIS. This article focuses on a particular type of actor within such innovation systems for $\mathrm{CO}_{2}$ utilisation referred as innovation intermediary.

Howells (2006: 720) defines an innovation intermediary as "an organization or body that acts [as] an agent or broker in any aspect of the innovation process between two or more parties". Innovation intermediaries are recognized as crucial actors that can facilitate the innovation process (Boon et al., 2011; Howells, 2006), support eco-innovation (Kanda et al., 2018), contribute to sustainable entrepreneurship (Gliedt et al., 2018) and transitions (Kivimaa et al., 2019a). Intermediaries facilitate the innovation processes by assuming different roles such as mobilising and distributing resources (e.g., Polzin et al., 2016), creating spaces for networking and collaboration between different actors (e.g., Hakkarainen and Hyysalo, 2016), and advocating for policy change and renewal among several other roles (e.g., Kivimaa, 2014). Sustainable entrepreneurship at the receiving end of intermediation activities is an essential driving force in the creation of ecologically and socially sustainable economic systems (Pacheco et al., 2010) and a vital ingredient for sustainability transition (Markard et al., 2012). Even though the literature on intermediaries continues to grow (see Gliedt et al., 2018; Kivimaa et al., 2019a), certain research gaps remain to be addressed. For example, until recently, there has been little research about the evolution of intermediaries (how they change over time) and the sustainment of innovation intermediaries' roles and activities over time (Hakkarainen and Hyysalo, 2016). A better understanding of the temporal dimension of intermediaries is relevant due to the fact that innovation intermediaries are key in the effective coordination of sustainability effect and market impact in sustainable entrepreneurship (Hörisch, 2015) and also due to the decades or even centuries that sustainability transitions take to materialise. Both large incumbents and new entrants such as startups can engage in sustainable entrepreneurship and impact sustainability transition by improving the sustainability performance and increasing the market share of new sustainability-oriented products and services (Hockerts and Wüstenhagen, 2010). And in particular, sustainability-oriented innovations such as $\mathrm{CO}_{2}$ utilisation technologies that use $\mathrm{CO}_{2}$ to produce fuels or chemicals (Styring et al., 2015), competing to substitute fossil resources on mass markets (Bocken et al., 2014), may not be economically viable from the start but require external change to bring viability in the future (ibid). Innovation intermediaries can amplify the necessary change for these technologies by advocating for them (e.g., Kilelu et al., 2011).

Based on this background, the purpose of this article is to contribute to the understanding of innovation intermediaries' survival (its countermeasure against ceasing to exist over time) by answering the following research question:

- What are the dynamics and the factors that affect an intermediary's survival over time? The rest of the article is structured as follows: Section 2 reviews previous literature to problematise the concept of intermediaries and intermediation, highlights research gaps and 
theories which are relevant for the guiding research question. The research methods used to collect and analyse the empirical data are presented in Section 3, followed by a presentation of the empirical results in Section 4 and their discussion in Section 5. Conclusions are drawn with implications for theory and policy in Section 6.

\section{Underlying concepts}

\subsection{The concepts of intermediaries and intermediation}

The concept of intermediaries continues to receive research attention in relation to different processes from innovation, to eco-innovation and to sustainability transitions. Even though the concept offers a common conceptualization to analyse entities which work by linking actors and the activities, skills and resources related to these actors to advance a given process (cf. Howells, 2006), the concept remains essentially contested. Scholars do not have a common view on how intermediaries and intermediation should be defined, how intermediaries should be identified in practice, and also their boundaries and relation to other concepts such as middle-actors, hybrid actors, third parties and boundary spanners (cf. Kivimaa et al., 2019a). Furthermore, some scholars view intermediaries as distinct entities (i.e. an organization, body or platform) while other consider intermediation as a process. This dichotomous view also influences the level of activity and influence affiliated to intermediaries as certain scholars regard them as passive in the processes in which they intermediate (Parag and Janda, 2014), while other contributions regard them as actively shaping the context and the interactions they inter-mediate (Hodson and Marvin, 2010).

The emergence of intermediaries in a given process also ranges from those strategically established to assume certain roles to others that emerge to assume certain roles due to a deficit in the given system or process. Thus, intermediaries are strategic actors with interests, skills and resources which they use to achieve certain objectives and to ensure their own survival as an entity (Kivimaa and Martiskainen, 2018). Furthermore, there are entities which assume intermediation roles without acknowledging it and thus it can be challenging to identify intermediaries in practice. As a consequence, several types of entities (e.g. consultants, architects, cities, universities, incubators, web platforms) have been empirically studied in the literature as intermediaries and thus intermediaries cannot be identified by the type of actor or organization. However, there is a large consensus in the literature that intermediaries work in situations where direct interaction is difficult or not desirable due to high transactions cots, information asymmetry or communication problems (Kivimaa et al., 2019a). Despite these differences, in its basic form, intermediaries are identified by their roles and relational work in-between different entities (Moss, 2009).

\subsection{Roles of intermediaries in innovation and sustainability transitions}

Traditionally, intermediaries have performed bilateral facilitating roles by assisting individual firms to reach their innovation objectives (Howells, 2006). However, as the innovation process has become increasingly complex involving several actors, their networks, and institutions, this one-to-one intermediation activities are being complemented by "systemic intermediaries" (van Lente et al., 2003). Systemic intermediaries do not operate on the individual firm or project level but rather on the network level, in innovation systems or socio-technical transitions (Kivimaa, 2014; Klerkx and Leeuwis, 2009; van Lente et al., 2003).

One of the most studied aspect of intermediaries is their roles in facilitating innovation processes and sustainability transitions (Martiskainen and Kivimaa, 2018). And by extension, there are different lists of roles attributed to intermediaries and with some redundancy between the different roles (Klerkx and Leeuwis, 2009). The roles attributed to intermediaries include among others articulation of needs and requirements, identification of needs, creation of business cases, communication and development, project management, managing external resources and organizational development, foresight and diagnostics, scanning and information 
processing, knowledge processing and combination/recombination, gatekeeping and brokering, testing and validating, accreditation, validation and regulation, protecting the results, commercialisation and evaluation of outcomes (Bessant and Rush, 1995; Howells, 2006). Stewart and Hysalo (2008) argue that the different roles of intermediaries can be grouped into facilitating - providing opportunities and space for other people to act; configuration adjusting the material and symbolic form of technology often in minor ways as well as how it is interpreted and used; and brokering - establishing, nurturing, adjusting and altering of connections between different actor.

A particular research gap in the literature regarding the roles of intermediaries in innovation is that apart from a few studies (e.g., Hakkarainen and Hyysalo, 2016; Martiskainen and Kivimaa, 2018), the roles of intermediaries have been studied as being static. In fact, as Martiskainen and Kivimaa (2018), put it, much of the literature has focused on the roles of intermediaries with little knowledge available on how intermediaries and their intermediation activities change over time. Furthermore, there is compelling empirical evidence to support the fact that the content and form of intermediary roles evolvs over time as a response to the changing context and for survival (Kivimaa and Martiskainen, 2018). Intermediaries' survival is particularly important because in order for them to facilitate the systemic changes needed for sustainability transitions, intermediaries need to have longevity as an organization and also they need to be capable of changing their roles, adapt their roles to evolving structures and also hold multiple roles at the same time (cf. Kivimaa et al., 2019b).

\subsection{Survivability of intermediaries and intermediation activities}

The literature identifies a number of factors which are important for the long-term survival of intermediaries and their intermediation activities. Kivimaa (2014) highlighted neutrality, i.e. independence of intermediaries from public administration and politics, finance or technology, as an important factor for the success and survival of intermediaries. Neutrality gives intermediaries trust among the different parties which they connect together. For example, being independent from public administration is regarded as particularly crucial for encouraging informal intermediation activities and also personal relationships between actors necessary to drive forward sustainability transitions (Matschoss and Heiskanen, 2017). Financial dependence of public administration can also be problematic for building trust since such authorities can limit the freedom of the intermediary to set their own agendas and also act freely indicating a level of lock-in to existing economic and institutional conditions (cf. Mignon and Kanda, 2018). On the other hand, technological neutrality refers to intermediaries not explicitly supporting a particular technology, and though such a stance is likely to increase trust among their clients, the urgency of climate change and sustainability transitions requires that intermediaries sometimes have to be outspoken and biased towards or even champion certain technologies or parties (cf. Klerkx and Leeuwis, 2009).

Furthermore, intermediaries also have to balance different kinds of demands and expectations placed on them by their stakeholders such as funders, clients which have direct influence on their present and future position (Klerkx and Leeuwis, 2009). For example, in the case of intermediaries operating within a triple helix structure (Barrie et al., 2017) and cooperative arrangements (Koppenjan, 2015) the strive to reach consensus and alignment can be complex and characterised by tensions. Another key issue regarding the survivability of intermediaries is with regards to source and stability of funding. Intermediaries can receive their funding from public and/or private sources and this can have significant impact on their intermediation activities (cf. Mignon and Kanda, 2018). The source of funding influences whether intermediation activities are generic or tailored to meet the specific needs of different groups and also if intermediaries seek long term strategic intermediation activities or are actively seeking to secure funding for their own survival (Hodson and Marvin, 2010). Achieving a balance between different types of expectations is particularly complex in the case of mixed 
funding (public-private). This gives rise to a social dilemma as intermediaries have to remain credible to the different actors, and balance between short-term with long-term considerations essential for their existence. For example, intermediaries which are initially publicly funded can also seek to or be mandated to be self-financing in the course of time as they become more established, independent and also their clients appreciate the importance of their intermediation activities (cf. Kivimaa and Martiskainen, 2018). Koppenjan (2015) identified tensions between sustainability and cooperative arrangements, especially when public budgets are shut down over time and private investments are required to step in. Moreover, those cooperative arrangements to form intermediary initiatives between public and private entities such as public-private partnerships (PPP) mostly fail because of the absence of a positive business case or positive return on investment (Akintoye et al., 2008; Hodge et al., 2010). Hence, Yaqub and Nightingale (2012) advocate for a more active management approach in PPP for difficult, timeconsuming and costly developments such as Carbon Capture and Storage (CCS) and $\mathrm{CO}_{2}$ utilisation.

Another important aspect for survival is the ability of intermediaries to generate internal value for themselves based on their interactions with clients (Silva et al., 2018). Internal value refers to the sum of both financial (e.g., service revenue, funding secured from research grants) and non-financial (e.g., social capital) values generated from their clients by intermediaries (Silva et al., 2018: 71). Other internal values that can be generated from the intermediation process include the development of new knowledge that intermediaries can generate from working on different projects or with different companies through cooperation, reciprocity and information sharing. Such accumulated knowledge is important in their intermediation activities and particularly when transferred from one client to another for effective intermediation (Geels and Deuten, 2006).

Moreover, Murphy et al. (2015) found that alignment of stakeholders positively affects the value creation in cross-sectoral collaboration. In particular, for intermediaries, such as those who create arenas for networking and exchange between different types of stakeholders, an established common vision is the basis for engaging the stakeholders in such intermediation activities. The common vision thereby "[...] represents the degree to which the members of the network share an understanding of and perspective on the achievement of the network's activities and results." (Expósito-Langa et al., 2015: 294). Furthermore, organisations with a shared vision benefit more from internal (absorptive capacity) and external (network positioning) resources (ibid.).

\subsection{Theoretical foundation}

In the innovation systems literature, the market failures approach as a basis for policy action is question as flawed and insufficient in explaining the emergence and diffusion of innovations but rather a systems approach is often seen as a more appropriate alternative (Bergek et al., 2008) or complement (Bleda and del Río, 2013). Though a number of different conceptualisations has been suggested regarding innovation systems (e.g., global innovations systems, regional innovation systems, sectoral systems of innovations and technological innovation systems), an overarching consensus in these conceptualizations is that, innovations emerge and diffuse in a dynamic context characterised by interactions between actors, their networks and institutions (Binz and Truffer, 2017). Thus, the innovation systems approach informs how innovations emerge in a particular context and build on concepts of path dependency, interdependency, lock-in and lock-out, co-evolution and feedback loops (Markard and Truffer, 2008).

A particularly relevant conceptualisations of the innovation systems for this article is the technological innovation systems (TIS) approach which is based on evolutionary and systems theory (Markard, 2018). More recently, Markard (2018) introduced key elements of a TIS life cycle (i.e. formative, growth, mature and decline phases) which can be particularly relevant in 
the analysis of transitions in which novel technologies emerge and diffuse while unsustainable alternatives decline. Intermediaries assume different roles in the TIS life cycle and are expected to contribute to the system functions in a TIS (cf. Lukkarinen et al., 2018). Following a TIS life cycle approach, intermediaries emerge during the growth phases of the TIS and eventually loose influence as the TIS declines and is replaced by another TIS (Markard, 2018). Finally, a potential caveat of the TIS approach is the risk of focusing on a particular technology and miss out on the relevance of other aspects such as social, organizational and institutional dynamics which are closely related to technological change (Markard, 2018).

Teece (2018) argues that "[ $\mathrm{t}]$ he systems approach lacks a place for proactive entrepreneurial action, viewing the system as primarily seeking to remain aligned with the survival requirements of the mega-system in which it is embedded." (Teece, 2018: 363). Though this approach is consistent with the evolutionary view of the firm (Nelson and Winter, 2009), it lacks the design aspect (entrepreneurship) for managerial decision making in strategic management (Teece, 2018). The dynamic capabilities framework, however, combines evolutionary (path dependence) and design elements alike (Augier and Teece, 2008) to maintain 'evolutionary fitness' over time (Teece, 2007). Hence, dynamic capabilities are suitable for analysing the factors of survival over time for innovation intermediaries as supporting body for entrepreneurship and innovation. Moreover, dynamic capability studies rarely investigate dynamic capabilities of innovation intermediaries as form of organisation (cf. Tjong Tjin Tai and Davids, 2016).

The dynamic capabilities framework builds - among others (cf. Teece, 2011) - on the systems approach and "[...] the enterprise and its extended market, technological, and regulatory environment [is viewed] as a whole, with many separate sub-systems to manage" (Teece, 2018: 366). The dynamic capabilities frameworks thereby consists of three elements (Teece, 2018): (a) capabilities, a hierarchy system of nested elements and activities (ibid.); (b) resources, including human capital, tangible and intangible assets (ibid.); and (c) strategies, "a coherent set of analyses, concepts, policies, arguments, and actions that respond to a high-stakes challenge" (Rumelt, 2011: 6).

Teece (2018) concludes that "[...] the strength of a firm's dynamic capabilities [a] determines the speed and degree to which the firm's idiosyncratic resources [b] can be aligned and realigned consistent with the firm's strategy [c]" (Teece, 2018: 366). However, the three framework elements overlap, are interdependent (Teece, 2018).

Altogether, the reviewed literature served as theoretical lenses through which we analysed the survival of intermediaries over time (see Table 1 for an overview of these lenses). The intermediary literature enables us to elucidate the roles and characteristics of intermediaries and how they changed over time, while the technological innovation systems literature provides an essential lens on the technological context within which the intermediary exists. The dynamic capability literature serves as a foundation for the analysis of innovation intermediaries in their changing environment to clarify barriers and drivers in achieving competitive advantage (cf. Eisenhardt and Martin, 2000; Teece et al., 1997).

Insert Table 1about here

\section{Research design}

The research is designed to capture the temporal dimension of the intermediation process in related fields of technology. A detailed analysis of innovation intermediaries at different stages (e.g., technological maturity, age of intermediary) is used to assess the dynamics in characteristics, scope, objectives, roles and activities, and to identify the factors of survival. A case study design with a comparative setting (cf. Eisenhardt, 1989; Eisenhardt and Graebner, 
2007; Yin, 2013) was chosen to examine four innovation intermediaries: two in the field of $\mathrm{CO}_{2}$ utilisation and two in the field of CCS. This design emphasises comparison within and across contexts to draw from causalities and acknowledges a well-developed methodology for project-based and systemic intermediation. The empirical setting was selected to be Europe, the USA and Australia. This selection is based on the existence of institutional framework that support sustainability-oriented innovation and with the ambition to show a diverse set of cases among which any similarity on their survival could be compelling.

\subsection{Sample and data collection}

The cases that have been carefully chosen in the field of $\mathrm{CO}_{2}$ utilisation, and CCS allow for an observation of similar $\mathrm{CO}_{2}$-related technologies at different temporal stages (e.g., technology maturity, age of intermediary) and broad geographical foci (national, supranational, global). $\mathrm{CO}_{2}$ utilisation converts $\mathrm{CO}_{2}$ molecules to other molecules in innovative approaches (Kant, 2017) whereas CCS captures $\mathrm{CO}_{2}$ mainly from point sources and stores it in geological formations (e.g., Styring and Jansen, 2011). Both, $\mathrm{CO}_{2}$ utilisation and CCS qualify for the need to coordinate sustainability effect and market impact (Hörisch, 2015). They have a high sustainability effect because they either increase resource efficiency, e.g., by substituting fossil resources with captured $\mathrm{CO}_{2}$ in production of specialty chemicals or intermediates (cf. Naims, 2016) or mitigate climate change, e.g., by capturing and storing large amounts of $\mathrm{CO}_{2}$ underground (cf. Styring and Jansen, 2011). In addition, they are on niche markets (Aresta et al., 2013) or the most costly technology to abate $\mathrm{CO}_{2}$ emissions (Nauclér and Enkvist, 2009) ${ }^{1}$. Hence, the related fields of technology reflect the underlying relevance of a need of coordination.

Technologies in both fields are at different stages of maturity (e.g., Styring and Jansen, 2011). However, on the four development levels (1) basic research, (2) R\&D, (3) demonstration, and (4) commercial application, the majority of CCS technologies are at a later stage in the demonstration phase (e.g., Bui et al., 2018; Coninck et al., 2009) and $\mathrm{CO}_{2}$ utilisation technologies are mainly in the R\&D phase transitioning to demonstration (e.g., Zimmermann and Schomäcker, 2017). Furthermore, intermediating actors in these two fields of technology have different ages. The average age of CCS intermediaries is 10.75 years and the average age of $\mathrm{CO}_{2}$ utilisation intermediaries is 2.75 years. All organisations in the sample have a clear focus on either $\mathrm{CO}_{2}$ utilisation or CCS. However, few technologies such as $\mathrm{CO}_{2}$ mineralisation and the enhanced recovery of resources (oil, coalbed methane or water) may be addressed by $\mathrm{CCS}$ and $\mathrm{CO}_{2}$ utilisation intermediaries alike, as these technologies utilise $\mathrm{CO}_{2}$ (converted into new molecules or non-converted as solvent) to generate economical value and (temporarily) store the used $\mathrm{CO}_{2}$.

The authors used a purposeful sampling approach to identify four critical cases (Palinkas et al., 2015) of intermediation for $\mathrm{CO}_{2}$ utilisation and CCS to make effective use of limited research resources (Patton, 2015). The paper's focus on these fields of technologies drastically reduced the population of intermediaries for sustainability-oriented innovation: the authors identified nine ( 3 in $\mathrm{CO}_{2}$ utilisation and 6 in CCS) ongoing (as of October 2016) initiatives that qualify as intermediary according to Howell's (2006) definition and are not primarily networking associations or conference providers; three in the field of $\mathrm{CO}_{2}$ utilisation and six initiatives in the field of CCS. The identification process was carried out by desk research (examples of keywords: "[field of technology] initiative*", "[field of technology] activit*", "[field of technology] program*", "[field of technology] association*". etc.) and the author's attendance at workshops and conferences in the field of $\mathrm{CO}_{2}$ utilisation and CCS in 2015 and 2016. Some

\footnotetext{
${ }^{1} \mathrm{CSS}$ is even considered as a non-profit technology because of its costs without current financial returns (https://setis.ec.europa.eu/setis-reports/setis-magazine/carbon-capture-utilisation-and-storage)
} 
of the identified initiatives were present at those events, others were recommended to the authors by experts in the respective field of technology (snowball sampling). The final case selection was based on the criteria of few and in-depth observations, the (perceived ${ }^{2}$ ) degree of a case's activity, accessibility of interviewees in management or steering positions, and a diverse and broad operational focus in the sample (see Figure 1).

The authors used existing and new personal contacts to knowledgeable individuals to start the data collection in 2016. Both, interviews and documentation have been used as a data source to compare $\mathrm{CO}_{2}$-related innovation intermediaries in Europe, the USA, and Australia. Furthermore, the analysis allowed for an empirical typology of the intermediaries in the sample (see Table 2): Following classifications and conceptual typologies from the literature (e.g., Howells, 2006; Kanda et al., 2015; Kivimaa et al., 2019a; Klerkx and Leeuwis, 2009) further communalities and differences in characteristics, scope, and objectives have been revealed.

Eight interviews have been conducted in person (in Germany and Australia) or via telecommunication between September and December 2017. A semi-structured open interview guide was used to explore characteristics, scope, objectives, roles and activities over time and to identify challenges and drivers in these dynamics. The following four items have been addressed:

- Introduction and background of entity and interviewee

- Characteristics and scope of entity (source of funding, governance, ownership, level of activity, innovation phase)

- Objectives and goals of entity (may include objectives of different partners or members)

- Roles and activities to achieve objectives

The interviews took between 22-62 minutes. All interviews have been recorded and transcribed to enable a rigorous data analysis. All interviewees have been asked for consent prior to participation in the study. Furthermore, interviewees approved the transcription when required and the interview data has been anonymised for the analysis. A detailed description of the interviews per case can be found in Table 2 .

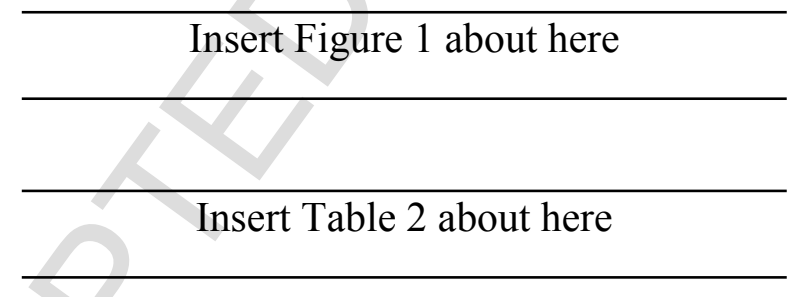

Publicly available and partially confidential documentation published between 2010 and 2017 has been used to triangulate the interview data and saturate the data collection process. The documentation ranged from presentations and webinars to detailed reports about the cases from the entity in the sample or from external sources. However, the age of the intermediary affected the availability of these documents (see Figure 2).

During the data collection process one case became particularly interesting due to its foreseeable termination by the end of 2017 . Hence, the focus on that case was deepened using multiple interviews with both operating and strategizing personnel from the lead partners of the initiative (see Figure 2).

\footnotetext{
${ }^{2}$ As most frequently reported by the experts or frequent participation at events
} 
Insert Figure 2 about here

\subsection{Data analysis}

A staged coding process (Strauss and Corbin, 2015) was used to analyse the data via the software Atlas.ti 8 (ATLAS.ti, 2018) and manual data extraction. Following Gioia et al. (2013) we structured our iterative analysis - where we went back and forth between the data and emerging theoretical themes and dimensions - in multiple distinct phases (see Figure 3).

First step (open coding): Revealing status quo, evolution, driver and challenges of innovation intermediaries

In an (semi-)open coding process the authors focused on keywords reflecting the status quo, evolution, driver and challenge of an innovation intermediary. Statements of the interviewees (quotes) have been iteratively categorised, and similar observed phenomena have been labelled so that codes and code categories emerged from the transcripts. As the role of a factor can change as a function of context, some factor may be a driver of an innovation intermediary in one circumstance and a challenge of an innovation intermediary in another circumstance (e.g., receiving public money in a volatile regulatory environment vs. receiving public money in a stable regulatory environment). Moreover, the distinction between driver and challenge may also be determined by the expression of a feature (e.g., having or not having external expertise). Hence, driver and challenge are considered jointly in the third step.

Second step (deductive coding): Describing the evolution (change over time)

Code categories reflecting the evolution as a dynamic of survival were then refined, condensed and further aggregated together with code categories reflecting the status quo into four theorybased code themes that were deductively queried in the interview: characteristics, scope, objectives, and roles and activities. The themes characteristics and scope were thereby broken down into sub-themes. All themes were derived from literature that describes and classifies innovation intermediaries based on conceptual typologies (e.g., Howells, 2006; Kanda et al., 2015; Kivimaa et al., 2019a; Klerkx and Leeuwis, 2009).

Third step (abductive coding): Identifying dimensions of survival

Code categories reflecting the driver and challenge were inductively condensed and further aggregated by manual extraction into 23 code themes in an axial coding process. Ultimately these categories were assigned to four overarching code dimensions. The main driver and/or challenge of innovation intermediaries were thereby abductively narrowed down to dimensions of survival that are also reflected in literature: neutrality - independence and legitimacy of an intermediary (e.g., Kivimaa, 2014), technological context - political, cultural and geographic context, and market structure that affect the technology an intermediary is focussing on (e.g., Kanda, 2017), shared consensus - shared consensus and alignments of an intermediary's stakeholders (e.g., Klerkx and Leeuwis, 2009) and internal value creation - creation of internal value for an intermediary to secure sustainment of its activities (e.g., Silva et al., 2018). This abductive approach (e.g., Timmermans and Tavory, 2012) of going back and forth between data and literature allowed for a coding that was "[...] guided by the material instead of following a set of predefined theoretical concepts" (Hahn and Ince, 2016: 38) and still theoretically sensitive (ibid.).

Additional step following the second step (deductive coding): Comparing roles and activities as proxy for the evolution

In a parallel process, codes in the code theme 'roles and activities' have been categorised based on an existing typology of intermediation roles from Howells (2006) to ensure that all relevant roles and activities have been covered. The authors choose this typology to maximise the information being captured in each type. Other typologies leave little room for comparison across the different types due to the limited amount of types (e.g., Stewart and Hyysalo, 2008). 
Howells (2006) divides the roles of an innovation intermediary into ten categories: (1) Foresight and diagnostics, (2) scanning and information processing, (3) knowledge processing, generation and combination, (4) gatekeeping and brokering, (5) testing, validation and training, (6) accreditation and standards, (7) regulation and arbitration, (8) intellectual property: protecting the results, (9) commercialisation: exploiting the outcomes, and (10) assessment and evaluation of outcomes. All documents have been coded using this typology via Atlas.ti's "auto coding" function to complete and triangulate the interview data. Search strings for the auto coding have been derived from the interview codes and all matches have been manually checked by the coder.

Information about the number of reported codes per Howells' (ibid.) category and case have been mapped to enable for a comparison between the fields of technology (see Figure 6). The field of technology is thereby used as a proxy for the temporal dimension. As stated in the data collection section, $\mathrm{CCS}$ and $\mathrm{CO}_{2}$ utilisation have a different level of technological maturity and the innovation intermediaries dedicated to either one of those fields of technology have different ages. Thus, the intermediary takes on different roles and activities depending on the current phase in its existence (see, e.g.,Hakkarainen and Hyysalo, 2016). Figure 6 highlights these differences in the roles and activities of intermediaries in the field of $\mathrm{CCS}$ and $\mathrm{CO}_{2}$ utilisation: The maximum amount of codes in each of Howell's categories (2006) from $\mathrm{CO}_{2}$ utilisation have been subtracted from the maximum amount of codes from CCS to shed light on the evolution along these technologies (see Figure 6).

Insert Figure 3 about here 


\section{Results}

This section presents the results as outcome of the coding process. Figure 4 and Figure 5 provide therefore an overview of the data structure. The data structure is also used to organise the results section: First, status quo and evolution will be presented based on the characteristics, scope, objectives, and roles and activities of the innovation intermediaries in the case study. Second, drivers and challenges as determinants for survival will be presented based on four dimensions: neutrality, technological context, shared consensus, and internal value creation. Aggregated code themes for these dimensions will thereby further help to structure this section.

Insert Figure 4 and Figure 5 about here

\subsection{Status quo and evolution}

The characteristics, the scope, the objectives, and the roles and activities of an innovation intermediary evolve over time. This section describes this evolution and provides an overview of the status quo of these categories and sub-categories (see Table 3). Furthermore, a comparison of the roles and activities per field of technology serves as proxy to give further insights about the evolution of intermediaries.

Insert Table 3 about here

\subsubsection{Characteristics (on a continuum from private to public)}

\subsubsection{Source of funding}

Case 1 got its initial funding from the government with the requirement to be financially selfsustaining in the future, whereas case 2 was initiated by industry and is mainly funded by private high-net-worth individuals, foundations, and corporates, but potentially - as planned in the future - also by governments via grant money. Case 3 and 4 were initiated with a similar funding structure by governments and received main funding from public actors such as national and regional governments. However, case 3 and 4 evolved from government-initiated organisations to private, not-for-profit organisations that financially self-sustain their operations. A minor source of funding from industry grew thereby over time to another substantial source. Both cases are currently funded by a mix of public and private sources ranging from membership fees over revenues to residual and new funds from governments.

\subsubsection{Ownership model and governance structure}

Case 1, 3 and 4 are membership-based, and case 2 was set up as a private not-for-profit organisation. Case 1 inherited its ownership model and governance structure from the coinitiating ${ }^{3}$ PPP, whereas case 2 is governed privately with an advisory board. The governance structures of case 3 and 4 was set up and remained as membership organisation with an (independent) board of directors.

\subsubsection{Scope}

The scope of each case is described by the level of activities, phase in the innovation process, operational area, and technology focus.

Case 1, 2, and 4 are predominantly active on a project level in the innovation phase of technology (and knowledge) development. However, some activities are also performed on a system level. Case 3 is mainly active on a system level with some activities on a project level.

\footnotetext{
${ }^{3}$ The other initiator came from industry.
} 
Furthermore, case 3 evolved from focussing on the development, demonstration, and deployment of technology to a focus on deployment and diffusion phase of innovation.

All cases, except case 3, which operates globally, concentrate their operations on a specific geographical region (USA, Europe or Australia)

Case 2, 3, and 4 have a broad technology focus and include all technologies from their field in their scope. Case 1 has a rather narrow focus on a technology pathway.

\subsubsection{Objectives}

Table 3 provides an overview about the current objectives of each case.

Overall, the objectives of intermediaries older than two years evolved:

- Case 3 shifted from accelerating the development, demonstration and deployment to accelerating the deployment of technology.

- After the decision to terminate the programme and the critical reassessment of the initial objectives, case 1 intended to shift from knowledge generation/development to the dissemination and diffusion of this knowledge after the evolution from a grant-funding programme to a financially self-sustaining programme failed.

- The vision of case 4 is not only to perform research project but also to operate the project outcomes such as demonstration facilities.

\subsubsection{Roles and activities}

Case 3 evolved from a role of combining and sharing knowledge to a role of actively advising decision makers, an opinion former and advocating for technology. Whereas case 4 intend to move from knowledge generation via research and demonstration projects to the application of accumulated knowledge for the active operation of demonstration facilities. Changes in the governance structure affected case 1's activity to recombine knowledge between partners: the programme management initiated project facilitation, e.g., via annual assembly to create synergies between project partner. Moreover, the shift from a focus on research to commercialisation was accompanied by a change of key performance indicators (KPIs) and consequently an evolution of the project evaluation activity.

More evolvement in roles and activities was planned or intended by case 1:

- Evolving from the role of a funding provider to a role of a funding broker that exploits external funding sources.

- Further activities to make use of effective communication channels to educate about the technology.

- User centric project exploitation via methodology-based toolkits (e.g., life cycle assessments or techno-economic assessments) for potential customers.

- Sharpen technology screening and commercialisation activities via the acquisition of experts in the respective field.

Table 5 gives an overview of the current roles and activities per case. Furthermore, it provides data about the reported codes in each of the 10 activity categories by Howells (2006). The various expressions of roles and categories based on Howell's framework can be compared on a technology level. Figure 6 give overviews about the comparison of $\mathrm{CO}_{2}$ utilisation and CCS intermediary's roles and activities: on the abscissa are the differences in the maximum number of reported codes per Howells' category, case and field of technology; negative numbers represent more reported codes in the field of $\mathrm{CO}_{2}$ utilisation and positive numbers represent more reported codes in the field of CCS. There are considerably more activities (2-3) in the categories protection of results, validation, regulation and arbitration, testing, validation and training, and gatekeeping and brokering of CCS intermediaries. Protection of results indicate the importance of intellectual property (IP) ownership for the internal value creation (see internal value creation). The categories validation, regulation and arbitration, and testing, validation and training reflect the activation that has been taken place in case 3 and 4 to create 
and capture more value beyond the knowledge generation. More activities in gatekeeping and brokering reflect the broad member base and its leverage for synergetic complementation, e.g., via networking. Furthermore, this broad and longstanding (established and consolidated) membership of the CCS intermediaries indicate little need for new partners and provide explanation for considerably more activities in the field of $\mathrm{CO}_{2}$ utilisation in the category scanning and information processing (see Figure 6).

Insert Figure 6 about here

\subsection{Survival}

The survival of innovation intermediaries is determined by drivers and challenges. There are at least four dimensions that influence the survival: (i) neutrality, (ii) technological context, (iii) shared consensus, and (iv) internal value creation.

\subsubsection{Neutrality}

The tensions of government involvement (initiation and constraints), the sources of funding, objectivity (governance, technology, decision making), and top-down changes are presented in this section.

Case 3 and 4 received the initial funding via a policy incentive aiming to address market failures or counteract the financial crisis. Their evolution was driven by the endeavour of the organisation and its members to be financially self-sustaining and not dependent or constrained by volatility of or obligations from government (see Table 4, Quote 1.2). How the members perceived the dependence on public funding were thereby one of the main drivers for case 3 to become financially independent (see Table 4, Quote 1.1).

The number of funding sources is also linked to financial independence. A single source of funding exposed case 1 to the risk of being dependent on the agenda setting of a single funder. The mix of funding sources in case 2, 3, and 4 helps to diversify this risk and sustain their operations over time. Case 2 gives evidence that such a diversification was intended when setting up the organisation to be entitled to attract public and private funding (see Table 4, Quote 1.3).

On the one hand, both organisations in case 3 and 4 appoint board members based on relevant skills and experiences within and beyond their membership to gain objectivity in decision making. Case 2 has a similar approach to achieve objectivity by unbiased expertise in its advisory board. On the other hand, a lack of objectivity biased the decision-making process throughout the existence of case 1 due to singular interest of the participating partners. Other potential conflicts of interests in the governance structure in case 1 and 2 were avoided by getting external advice to optimise the structure.

Moreover, objectivity towards technology was one of the driving forces in case 2 and 3 to gain credibility for advocating for a holistic field of technology (see Table 4, Quote 1.4 and 1.5). By contrast, case 1 had a narrow focus on certain technologies in the field of $\mathrm{CO}_{2}$ utilisation and a single-sided representation of industry in its membership. This focus and membership helped to agree upon and initiate the programme, but limited case 1's capacities to advocate as the opinion representation is not unbiased (see Table 4, Quote 1.6).

The role that the external advisors played in case 1 , however, was not well defined. Moreover, a series of organisational and personnel changes of a lead partner (e.g., because of conflict of interest) resulted in changes of the composition of managing and decision-making bodies over time (see Table 4, Quote 1.7). Challenges in this regard arose from top-down decision making from the funder and subsequently lead partner to strategically realign towards business creation 
and introduce new metrics to measure success. These measures implied to operate on a timescale as near-term as possible (create businesses within 1-3 years) in a field of technology with long development times (5+ years) (see Table 4, Quote 1.8). These changes on multiple levels simultaneously led to de-prioritisation of the re-structuring process of the governance (see Table 4, Quote 1.9). Furthermore, the intermediary needed to adapt to the top down decision making by changing its activities and imposing these changes its members/partners.

\subsubsection{Technological context}

The context of the innovation intermediary is primarily given by the addressed field of technology. Themes in this dimension were about proximity to the technology, the potential of the technology, and conditions of policy, market and technology.

A rationale for the geographic focus of case 2 is the proximity to the technology and its associated ability for hands-on interaction.

Even though most cases were initiated by governments and the potential of the technologies (e.g., keeping key industries in Europe, turning a waste into a resource) (see Table 4, Quote 2.1 and 2.2) positively affected the technology focus (e.g., by international agreements to favour certain technologies), effects by (i) market, and (ii) policy making, and (iii) technology development, were also reported to be negative in nature:

i. The demand for technological applications is necessary and partially non-existent. Suitable products and market acceptance are partially missing as well.

ii. The lack of policy support such as universal carbon price or accountability of carbon capture in emissions trading systems and dependencies such as on the price of petroleum challenged the focus on concerned technologies (see Table 4, Quote 2.3). Furthermore, this focus was negatively affected by room for interpretation in national implementation of supranational legislation and ineffective coordination between executive authorities to align agendas (see Table 4, Quote 2.4) or between funding programmes to avoid redundant technology funding.

iii. Long technology development times (5+ years) and a lack of technology success stories mismatched the expectations of funders (e.g., to have economic, environmental and social returns simultaneously) and industry (e.g., decrease failure rate of projects) (see Table 4, Quote 2.5).

However, the lack of success stories in commercialising the technology and the consequent lack of buy-in from the industry lead to case 2's opportunity recognition and focus on $\mathrm{CO}_{2}$ utilisation in the first place.

\subsubsection{Shared consensus}

This dimension is specified by themes about multi-stakeholder relationships, buy-in of partner, partner alignment, mix of partners, and expectation management.

Case 2 perceived the collaboration of relevant actors from policy, technology, and markets as key to achieve its objectives. But multi-stakeholder relationships can also be a source of challenges. Case 1 was set-up in an area of tension between different triple helix actors (university, industry, and government) within a PPP, however, the governance structure did not reflect a fully developed triple helix as the government pillar was merely represented by the funder making top-down decisions. Thus, a full institutional overlap between government, academia and industry was absent.

Another perceived key element for the success of an intermediary was attributed to the team and its individuals by case 1 . Especially the buy-in of the partners was critically reflected upon in case 1: the buy-in of the partners was generally missing, and a shared vision and a team spirit were absent (see Table 4, Quote 3.1). The relationship between the intermediary and its partners in case 1 remained transactional rather than evolved to the desired impact relationship. 
However, case 1 and 2 give also examples on how buy-in was (planned to be) achieved: Project facilitation via annual partner meetings was driven by the wish to activate and motivate a subcommunity of a lead partner in case 1 (see Table 4, Quote 3.2). Furthermore, case 2 took advantage of its ownership model to release its members from liability (e.g., for capitalintensive demonstration projects) to incentivise its membership.

Other challenges that arose in case 1 were in the field of partner alignment. Partner objectives and interests diverged (e.g., climate-impact via immediate commercialisation vs. competitive advantage via advocacy vs. research sponsorship via grant money) and were difficult to align - especially after the self-sufficiency requirements were introduced. There was an inability to group and apply for third party funding with the current mix of partner (see Table 4, Quote 3.3). In case of an alignment, the process took a long time (see narrow technology focus). Case 1 's narrow focus on a certain technology in the field of $\mathrm{CO}_{2}$ utilisation was agreed upon in workshops with the programme-initiating partners; but, as only a few partners were involved in this process a consensus across all relevant stakeholder was impaired.

This narrow focus within the field of technology (see neutrality) in combination with a narrow membership of few industry representatives and research organisations constraint the ability to formulate and represent (advocate) a joint opinion for this field of technology towards policy maker. Furthermore, the mix of partner in case 1 limited its ability to adapt to the new topdown requirements to be financially self-sustaining (see Table 4, Quote 3.4).

Overall, the contribution of the intermediary and the contribution of its partners was not clearly defined (see Table 4, Quote 3.5). This lack of clarity led to several challenges in managing expectations of the involved stakeholders. On the one hand, the funder in case 1 introduced new KPIs that move away from pure knowledge generation towards business creation to encourage a more value for money attitude within the membership where the intermediary expected its project partners to engage in exploitation activities. On the other hand, the project partners expected ongoing funding to carry on their $R \& D$ as integral incentives of being part of the programme (see Table 4, Quote 3.6).

\subsubsection{Internal value creation}

This section is about how an innovation intermediary manages to create value internally. Themes in this regard are: size of funding. vertical integration, complementing activities and relationships, competencies and knowledge, leadership, self-organisation, exploitation management (value creation), enlightenment, and communication and involvement.

The intended evolution of case 1 to financial self-sustainment via private (e.g., membership fees) and public money (e.g., grant money) posed a discrepancy between the available money and the monetary requirements for R\&D in this field of technology (see Table 4, Quote 4.1), let alone the monetary requirements to grow (e.g., broaden scope of technology and industry). Cuts in the budget of case 1 limited also the capabilities to incentivise new and existing partners. Case 3 evolved and case 4 plan to evolve from knowledge generation and sharing to advising and advocating or operating facilities based on the accumulated knowledge over time. Both cases capture thereby more value in terms of applying knowledge for advocacy and consultancy (case 3) or for the operation of demonstration facilities (case 4) (see Table 4, Quote 4.2).

Both cases benefit from their broad membership and fall back on vast networks for advocacy or research and demonstration. Furthermore, the two cases are in a synergetic relationship and benefit from one another (see Table 4, Quote 4.3). Case 2's focus on technology development as an early stage intermediation is due to the fact that later stage intermediation needs a steady supply of new technologies to commercialise and to deploy. Vice versa early stage intermediation needs the money and partnerships from later stage intermediation. Moreover, case 1 and case 2 reported further activities to engage in complementing relationships either alongside a specific value chain or with various key actors in science and industry. 
There was an absence of knowledge on various levels in case 1: Firstly, technical knowledge to objectively assess the technologies in the field (e.g., understand its potential at the beginning of the intermediation process, methodologies to properly assess technologies). Secondly, market knowledge to understand the different fields of application in various industries. Thirdly, policy knowledge to fully engage in advocacy. Lastly, product development knowledge to create internal value for the intermediary from the various project outcomes. The realisation of that absence and the consequent involvement of external expertise was late (see Table 4, Quote 4.4). Although, existing competencies and knowledge in case 1 and case 2 pre-determined the economic niche/scope of the intermediary at the beginning.

These competencies were also the rationale for the two cases to (attempt to) take on a leadership role as they would combine all relevant knowledge in science/technology and industry/market for the intermediation of this field of technology. Furthermore, case 4 perceived the leadership as key in achieving it objectives. However, case 1 failed to become a thought leader due to a lack of self-organisation and management.

Overall, there was a lack of (self-)organisation and management in case 1 to become thought leader (see Table 4, Quote 4.5), to secure additional funding and sustain operations, and to untap potential to create synergies by, e.g., sharing project partner's existing infrastructure. The continues strategic re-alignment between lead partners and funder (top-down) left little room for decision making on the organisational level (bottom-up) of case 1; leaving the programme management caught up in implementing the top-down requirements at the expense of managing the stakeholder. Moreover, the absence of key personnel led to an underperformance of roles such as facilitator to leverage on the connections between the project partners and to operationalise synergetic effects between them.

The new metrics discouraged pure knowledge generation and those partners that mainly engage in research activities: Project-based activities in the domain of technology development and research were challenged to fulfil the new funder KPI's on business instead of knowledge generation and mainly seized to exist after the termination of the programme in case 1 (see Table 4, Quote 4.6). Furthermore, new partners were mainly assessed on their capability to preserve some of the programme's outcomes rather than carrying on or even scaling-up (broadening the technology focus) activities such as knowledge generation.

Case 1 was rather limited in its value creation by inabilities in exploitation management: It was neither able to leverage on the project outcomes by develop products for the intermediary to generate revenue to meet the requirement to become self-sustaining (find a working selfsustaining business model) (see Table 4, Quote 4.7) nor to incorporate user-centric aspects in this project exploitation. The absence of a formal technology transfer role such as a dedicated product manager for case 1 led to a lack of exploitation of the project outcomes.

IP is another area within the exploitation efforts of case 1. The partner, not the intermediary holds the IP of project outcomes. The partners' attitude towards competition had a direct effect on the openness of innovation and restraint it rather than to embrace it.

Enlightenment in case 1 has been taken place in form of social acceptance projects to create awareness about the risks and opportunities of the technology in order to counteract irrational fears in society and to educate about the technology. Education is also perceived by case 4 as a key factor to successfully fulfil its objectives. Moreover, the standardisation efforts for the assessment of the technology was motivated by incapability of, e.g., investors to make qualified decisions about the technology. Similarly, unbiased, evidence-based expertise were also driven by requirements for competent decision making.

The last theme is communication and involvement. The knowledge dissemination capabilities of case 1 were limited by time constraints to engage, e.g., in more round table discussions or breakfast meetings and by a lack of traction of communication channels, e.g., online learning platforms. This also affected the identification process of partners to sustain project outcomes 
after case 1' termination (see Table 4, Quote 4.8). Similarly, interaction with policy maker was rather out of scope due to a lack of understanding for advocacy in the field of technology: neither the role of the technology nor the role of case 1 were fully understood. It follows that few policy discussions lead to an underperformance of actionable recommendations for stakeholder such as decision maker, opinion former and representatives of the civil society. Furthermore, the communication with budget owners and open innovator was challenging due to their limited understanding about the technology. Likewise, there was a conflict around the involvement of the end customer (drop in-solution vs. active involvement of customer via toolkit solution) (see Table 4, Quote 4.9).

Insert Table 4 about here 


\section{Discussion}

From our empirical studies, we described the evolution of intermediaries based on four themes: (a) characteristics, (b) scope, (c) objectives, and (d) roles and activities. Furthermore, we identify at least four dimensions of intermediaries which influence their survival over time. These dimensions are: (i) neutrality, (ii) technological context, (iii) shared consensus, and (iv) internal value creation. All dimensions represent thereby either the internal, external or both domains of an innovation intermediary. The internal domain is covered by the internal value creation and the ability of the entity to manage its internal resources purposefully and adapt its resource base to external influences. The dimension of technological context embodies these influences and presents the external domain. Both, neutrality and shared consensus are dimensions that bridge the external and internal domain via interactions of the internal entity with external stakeholders.

In the following section the authors discuss the evolution and the four dimensions of survival.

\subsection{Describing the evolution}

An intermediaries' roles and activities change over time to adapt to evolving structures and conditions. The cases in this study went through changes over time to stay operational and cater for the shifting needs and requirements of its stakeholders. However, not only the roles and activities evolved but also objectives, scope and characteristics altered. The characteristics (e.g., source of funding, governance structure, and ownership model) tend to move on the continuum from public to private, whereas the scope tend to evolve alongside the maturity of the technology and/or intermediary. Given the maturing of intermediaries and the accumulation of resources (especially knowledge), objectives become more ambitious to cover more parts of the value chain. This goal to increase the added value over time is also reflected in the evolution of the roles and activities: moving from information screening and knowledge generation towards demonstration (testing, validation), negotiating, exploitation (incl. IP), and advocacy (see Figure 6). Thus, the intermediary meets the requirement to differentiate itself from other similar service providers on the market.

\subsection{Neutrality}

We found that financial independence was one of the key drivers for the intermediaries in our sample. Particularly case 1 struggled to become financially self-sustaining and thereby failed to ensure its future operations. To develop intermediation activities that can be sustained over a period of time, it be necessary for intermediaries to secure a stable financing. The stability of the funding is particularly important because, such a situation reduces the risk of intermediaries seeking their own interests and survival at the peril of the interests of their clients or target group. And as Hodson and Marvin, (2010) discusses, intermediaries with stable financial support are less likely to risk the priorities of intermediation to be involved in chasing funding for their own survival which often have associated targets, objectives, and commitments which may not be in line with the interest of the intermediary and its clients.

Thus, depending on other actors for financial support can limit the degree of freedom an intermediary has to set its own agenda and act freely as pointed out in other previous literature (e.g., Klerkx and Leeuwis, 2009).

Furthermore, sustained broad based financial support also means that, key persons in the intermediary can be retained, trained and incentivised over time and their intermediation activities are thus sustained and committed to the intermediary organisation. We showed that the top-down decision-making lead to a series of challenges in governing the intermediary which can threaten the existence of the intermediary over time. Obtaining technology neutrality, e.g., via external supervision and advise or an unbiased understanding of technology and membership was one of the key drivers in our cases to gain legitimacy. 


\subsection{Technological context}

The context of an intermediary depends on the technology the intermediary is focussing on and the phase of the technology: i.e. development, demonstration or diffusion. Our findings indicate the relevance of context for the cases' fields of technology with regard to technology itself, market and policy. The political context is expressed by different policies that affect the technology or the intermediary. Policy interventions and regulatory pressure can also be discussed as a lever to overcome barriers for sustainability-oriented innovation. However, these interventions can lead to further dependencies and challenges in the neutrality of an intermediaries. Consequently rapidly changing policy context can directly affect the activities of intermediaries as they have to repackage their activities for each new policy changes and funding opportunity (Kivimaa and Martiskainen, 2018). Legitimacy through the acceptance of the technology are of upmost importance in the field of CCS (Dütschke et al., 2016; e.g., Kraeusel and Möst, 2012) and cannot be neglected in the field of $\mathrm{CO}_{2}$ utilisation (c.f. Jones et al., 2017). In $\mathrm{CO}_{2}$ utilisation $\mathrm{CO}_{2}$ could be considered as a resource, whereas CCS deals with $\mathrm{CO}_{2}$ as a waste/emission. Nevertheless, the geographical context in form of resource availability and waste streams is equally important.

The market structure is interwind with the political context in both fields of technology. The price of $\mathrm{CO}_{2}$ effects both areas. Furthermore, $\mathrm{CO}_{2}$-based products must compete with fossilbased products and therefore depend on the price of petroleum. Regulatory frameworks can therefore directly impact these technology, e.g., with demand-pull policies (e.g., Peters et al., 2012).

$\mathrm{CO}_{2}$ utilisation and CCS are in a similar technological context. However, there are differences from the maturity and the application of the technology. $\mathrm{CO}_{2}$ utilisation is mainly in the technology development phase and mainly finds application as a resource efficiency technology. CCS is mainly in the demonstration phase and mainly finds application as a $\mathrm{CO}_{2}$ mitigation technology. The technological context needs to be acknowledged by all actors in the respective field of technology. Especially, the funder and initiator of the intermediary needs to develop a contextual understanding to establish structures that enable the intermediary to sustain its business operations over time.

The different technology phases within which the intermediary operates also influence the funding available. For example, whereas public funding is more prominent in the early stage of technology development (research and demonstration phase), private funding gets more relevant in later stages (commercialisation and diffusion phase) (cf. Markard, 2018). Our findings support this line of argumentation: the intended change in the source of finance (from public to private) in case 1 mismatched the innovation phase of $\mathrm{CO}_{2}$ utilisation (mainly research and demonstration). It is therefore crucial for decision maker to not only understand the field of technology and the corresponding innovation phases but also to set feasible parameters, e.g., KPIs and to implement an appropriate funding scheme for the intermediary.

\subsection{Shared consensus}

We discovered that a shared consensus was largely absent and an alignment of stakeholders challenging due to diverging interests and expectations in case 1 . The value creation in the collaborative efforts of multiple sectors in the field of CCS or $\mathrm{CO}_{2}$ utilisation ${ }^{4}$ is therefore impaired by the lack of alignment.

Sharing consensuses with the broader community and other key stakeholders of the intermediaries is important for creating legitimacy, and visibility for the intermediary and also in attracting clients and members (cf. Hodson and Marvin, 2010). A triple helix structure with the representation of actors from government, industry and academia can offer mechanisms to

\footnotetext{
${ }^{4}$ See Styring and Jansen (2011) for an overview of the involved sectors.
} 
reach consensus in multi-stakeholder relationships within an intermediary (see also Barrie et al., 2017). In view of case 1, we found that a triple helix structure was inherited by the intermediary, but there was an imbalance in the decision-making power and representation of each actor. And for longevity, it is equally important to align and share consensus on current needs and expectation as well as evolving ones in-line with the expectations of various stakeholders.

\subsection{Internal value creation}

In order for intermediaries to exist and successfully create value for their clients, they need to generate internal value for themselves through their interactions with clients (Silva et al., 2018). We observed that case 1 was challenged to expand its single source of funding and failed to leverage its project outcomes, whereas the other cases could rely on a mix of funding streams. Our findings also show that knowledge has been generated and accumulated in all cases, but especially intermediaries in the field of $\mathrm{CO}_{2}$ utilisation did not (yet) fully apply the knowledge, e.g., for advocacy or plant operation (see case 3 and 4). Furthermore, our findings show the absence of relevant knowledge on several levels in case 1. As Geels and Deuten (2006) discusses, by accumulating knowledge from different intermediation activities, intermediaries are able to create, maintain and distribute abstracted knowledge that can be used within a broader technological field even on a global scale.

Moreover, intermediaries through their activities develop networks with several stakeholders including companies, and such networks can be particularly important when seeking partners for collaborations and providing support services for innovation development. We found that efforts to increase the membership and to interact with relevant stakeholder was hindered by limitations in the communication, and a lack of (self-)organisation and management in case 1. Contrary to these obstacles, we discovered that case 3 and 4 managed to leverage their network and to engage in a synergetic relationship with other intermediaries in their field of technology. Case 1 gives empirical evidence for a tension between sustainability and cooperative arrangements (cf. Koppenjan, 2015) as it failed to align the various objectives and requirements from funder and (lead) partners to get economic, environmental and social impact in the near term. Case 4 on the other hand managed to sustain its business by evolving from an initiated PPP to a private organisation over a period of 11 years.

Intellectual property can be another source of internal value creation for intermediaries. We found a lack of intellectual property (IP) ownership in the field of $\mathrm{CO}_{2}$ utilization intermediaries (case 1 and 2) that can limit the intermediary's capacities to act as arbitrator.

\section{Conclusion}

\subsection{Strategies and recommendation}

We synthesize four dimensions influencing the survival of innovation intermediaries in this article to derive recommendations for policy makers and innovation intermediaries. Even though the empirical setting in this study focussed on $\mathrm{CO}_{2}$ utilisation and CCS, our observations and thus recommendations are not limited to current and future actors in these specific fields of technology (this may be also true for pure networking associations and conference providers when they decide to broaden their activities). Stakeholders with a similar need for coordination between a technology's sustainability effect and market impact, may also gain a better understanding on potential factors influencing the evolution and survivability of intermediaries that engage in this area of tension.

Policy makers should consider the nature of sustainability-oriented innovation and technology when formulating their requirements (e.g., KPIs) for innovation intermediaries. This requires specific knowledge about targeted fields of technologies. Especially the technology development time and cost should be acknowledged and reflected in dedicated requirements for innovation intermediaries. These dedicated requirements will help to align (a) activities to 
meet the requirements of the policy maker and (b) activities to meet the objectives of the intermediary. Aligned activities will thereby increase the neutrality of the intermediary. Furthermore, policy makers in triple helix arrangements should move beyond making topdown decisions by imposing their requirements onto initiated intermediaries to engaging in the triple helix coordination by being part of these intermediaries.

Intermediaries should be aware of relevant expertise in their fields of technology, market and policy. Both internal knowledge that is built up and maintained and external knowledge that is acquired from partners or third parties should retain its neutrality. This neutrality will make intermediaries' voices heard better when advocating and will help to gain legitimacy in alignment processes. Moreover, intermediaries in a triple helix setting should engage all triple helix actors to reach consensus and legitimacy for long-term decision making. Effective selforganisation and management will not only help in the alignment of partners, but also in the creation of internal values. Intermediaries should cater for the stakeholder demands and expectations of different stakeholders by striking a balance between them using multiple value propositions.

\subsection{Theoretical implications and future research}

This study syntheses four interrelated dimensions that influence the survival of innovation intermediaries over time. Although the authors are aware that there might be additional dimensions, the identified aspects of neutrality, technological context, shared consensus and internal value creation contribute to the literature by creating a greater understanding of an intermediary's survival. In fact, even though the longevity and survival has been highlighted as an important aspect of intermediaries and demanding research attention (Kivimaa, 2014), to the best of our knowledge, this is the first article to provide such a comprehensive overview on intermediary survival. In addition, we show that not only the roles and activities, but also the characteristics (e.g., source of funding, governance structure, and ownership model), scope and objectives of innovation intermediaries change over time. Research in the field of innovation intermediaries and their roles and activities have a rather static nature. Even in cases where intermediaries have been studied as being dynamic, the focus has mainly been on their roles and activities (e.g., Kivimaa et al., 2019b). This study, however, shows that intermediaries and their intermediation activities are not static but dynamic and intermediaries have to make strategic decisions with regards to their characteristics, scope and objectives to survive over time. In addition, we contribute to the dynamic capability literature (Teece, 2011, 2018) by applying the theory and its concepts to fruitfully analyse the survival of intermediaries over time and thus broadening its scope of applicability from firms to other forms of organization such as intermediaries.

The authors took advantage of the termination of one of the cases during the data collection and consequently acknowledge the relative in-depth focus on this case. A longitudinal study in the same field of technology with a single in-depth case can reveal further insights into the evolution of an intermediary and its roles and activities by differentiating the four aspects, investigating interactions between the aspects or identifying further dimensions. Nevertheless, the diversity in this study allowed for comparison and valuable insights across similar fields of technologies, countries and maturity of intermediaries and technology.

\section{Acknowledgements}

This work has been mainly accomplished in the frame of the $\mathrm{EnCO}_{2} \mathrm{re}$ programme, funded by the European Institute of Innovation and Technology's Climate-KIC. The authors are particularly grateful to the individuals that participated in this study. Insightful comments and suggestions by the FGF's sustainable entrepreneurship working group members helped to improve an earlier version of this manuscript. Furthermore, the author wants to express a 
special gratitude to Prof. Dr. Jan Kratzer and Prof. Dr. Olof Hjelm for their continuous supervision and support.

\section{Funding}

This work has been partially funded by the European Institute of Innovation and Technology (EIT) via the EIT Climate-KIC flagship programme "EnCO ${ }_{2} \mathrm{re}-$ Enabling $\mathrm{CO}_{2}$ re-use". Wisdom Kanda's working time on the article was funded by the European Union Interreg project - SUPER (Supporting eco-innovations towards international markets). 


\section{Figures and Tables}

Table 1: Overview of underlying concepts

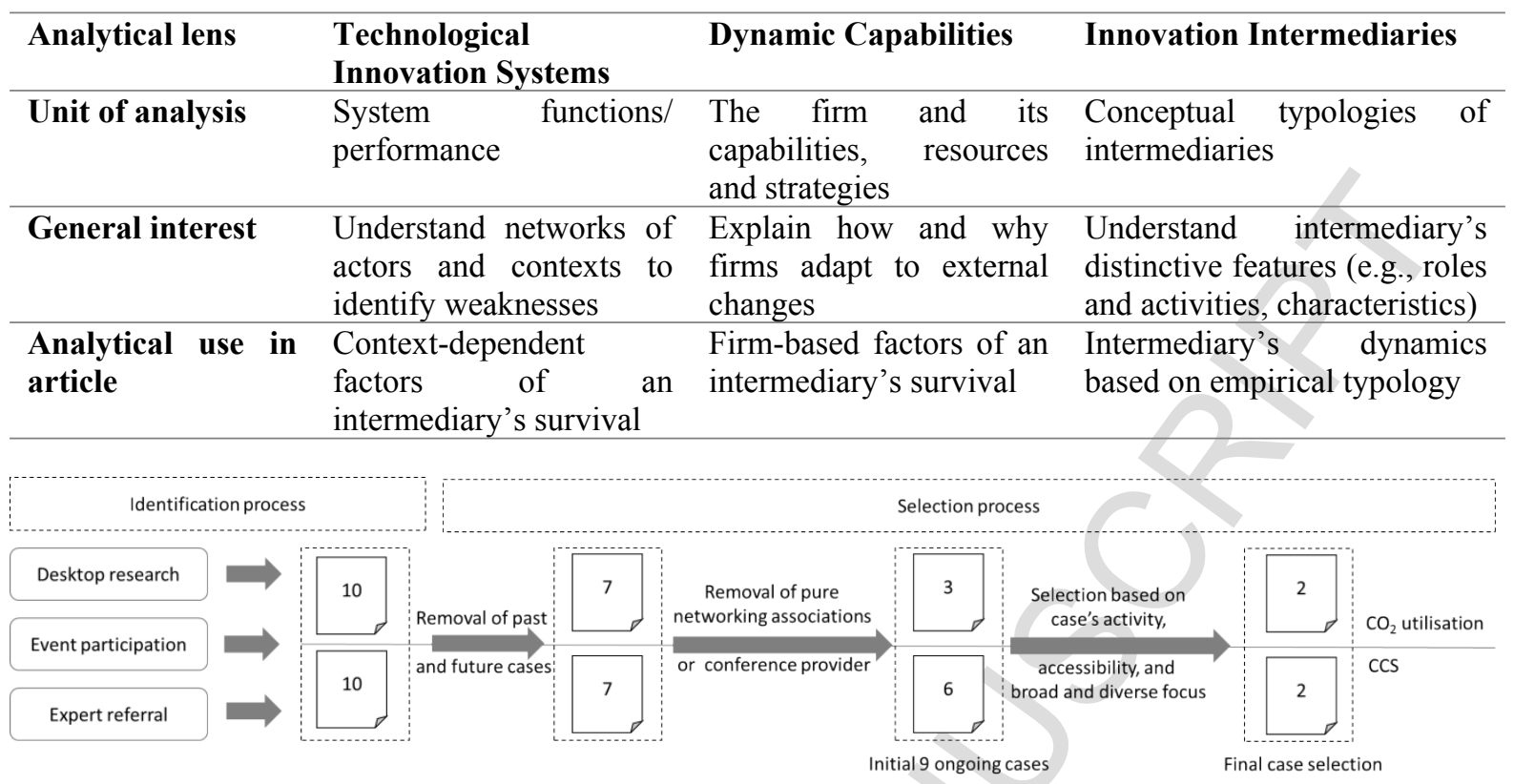

Figure 1: Overview of sampling process

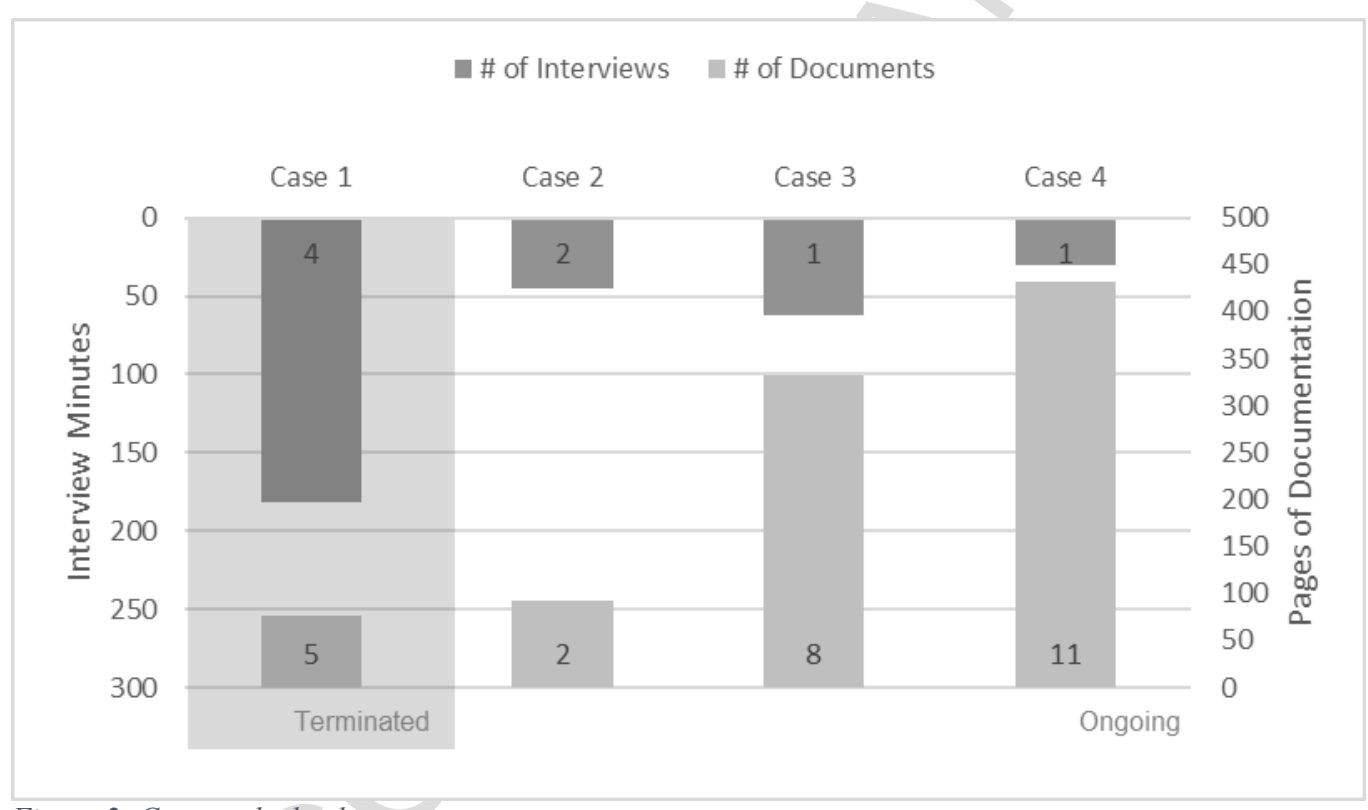

Figure 2: Case study depth 


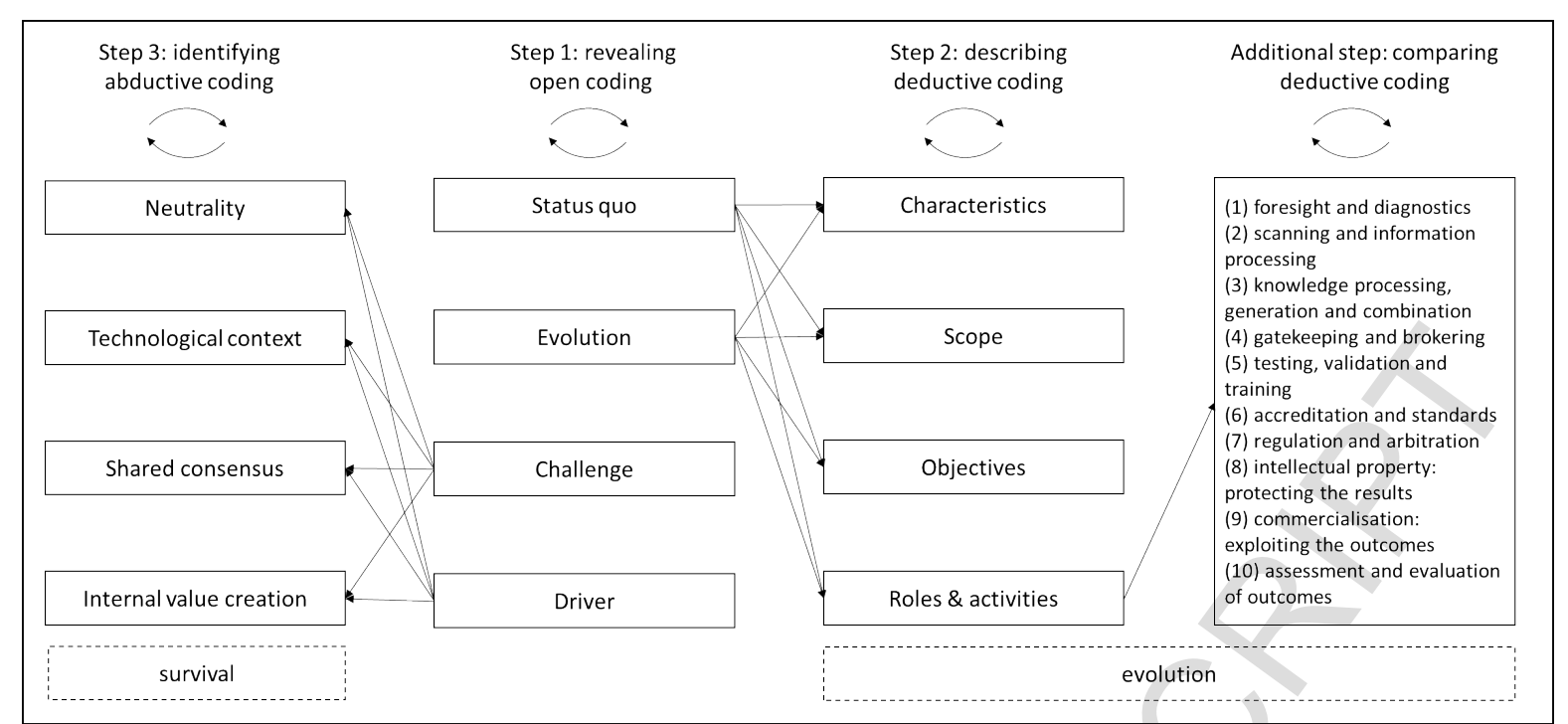

Figure 3: Coding process 
Table 2: Case study overview (long)

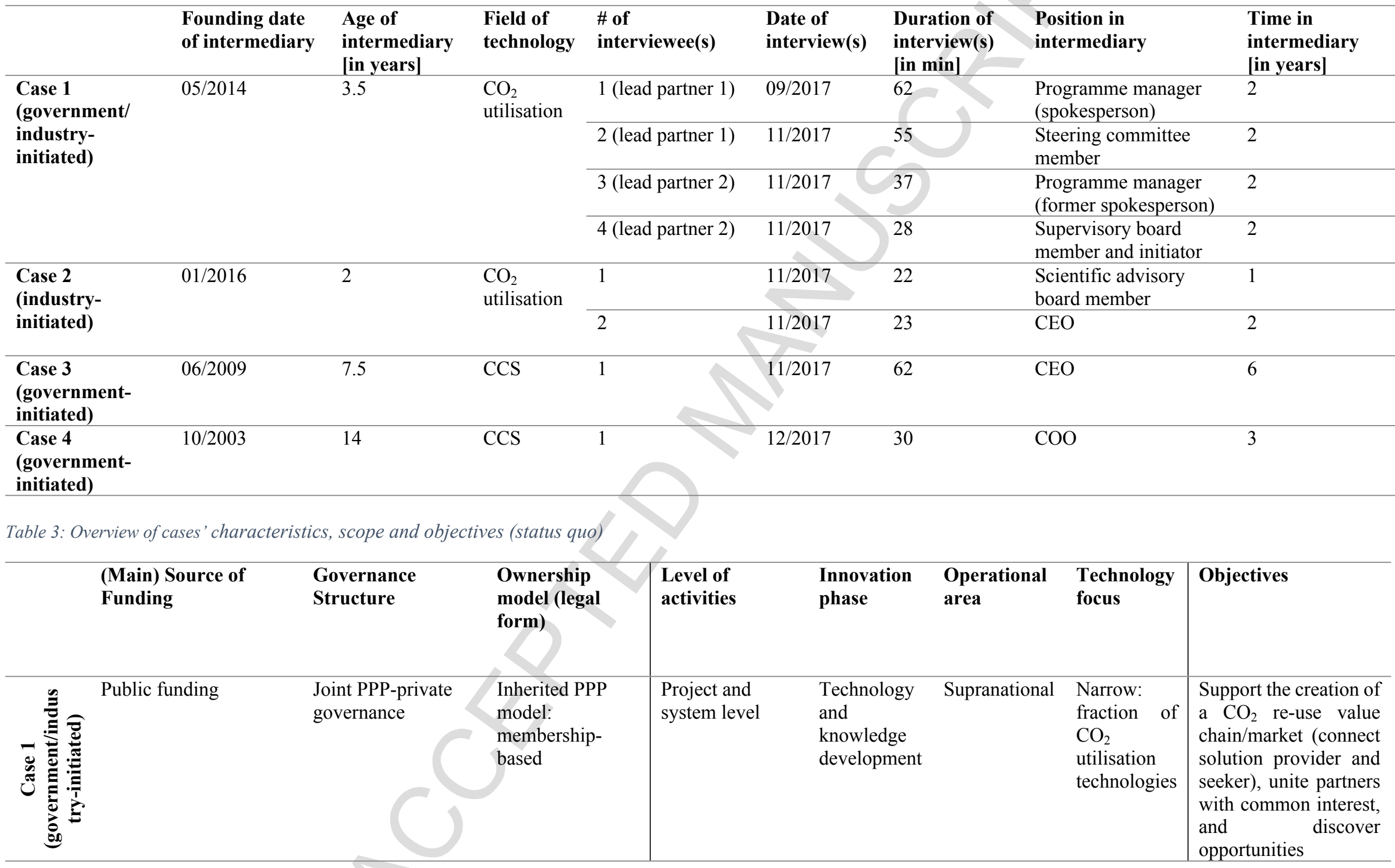




\begin{tabular}{|c|c|c|c|c|c|c|c|}
\hline 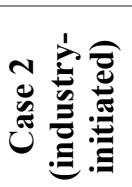 & Private funding & Privately governed & $\begin{array}{l}\text { Private not-for- } \\
\text { profit } \\
\text { organisation } \\
\text { (charity) }\end{array}$ & $\begin{array}{l}\text { Project and } \\
\text { system level }\end{array}$ & $\begin{array}{ll}\text { Technology } & \text { National } \\
\text { development }\end{array}$ & $\begin{array}{l}\text { Broad: all } \\
\mathrm{CO}_{2} \\
\text { utilisation }\end{array}$ & $\begin{array}{l}\text { Promote and catalyse } \\
\text { the deployment of } \\
\text { carbon conversion } \\
\text { technologies }\end{array}$ \\
\hline 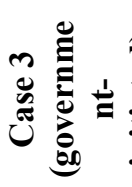 & $\begin{array}{l}\text { Mix of public and } \\
\text { private funding }\end{array}$ & $\begin{array}{l}\text { Governed as private } \\
\text { and public member } \\
\text { organisation }\end{array}$ & $\begin{array}{l}\text { Government- } \\
\text { initiated private } \\
\text { membership } \\
\text { organisation }\end{array}$ & $\begin{array}{l}\text { System and } \\
\text { project level }\end{array}$ & $\begin{array}{l}\text { Deployment Global } \\
\text { and } \\
\text { diffusion }\end{array}$ & $\begin{array}{l}\text { Broad: all } \\
\text { CCS }\end{array}$ & $\begin{array}{l}\text { Accelerate the } \\
\text { deployment of CCS, } \\
\text { capacity building in } \\
\text { non-OECD countries }\end{array}$ \\
\hline 党 & $\begin{array}{l}\text { Mix of public and } \\
\text { private funding } \\
\end{array}$ & $\begin{array}{l}\text { Governed as private } \\
\text { and public member } \\
\text { organisation }\end{array}$ & $\begin{array}{l}\text { Government- } \\
\text { initiated private } \\
\text { membership } \\
\text { organisation }\end{array}$ & Project level & $\begin{array}{l}\text { Technology National } \\
\text { development } \\
\text { (TRL 1-7) }\end{array}$ & $\begin{array}{l}\text { Broad: all } \\
\text { CCS }\end{array}$ & $\begin{array}{l}\text { Demonstrate } \\
\text { improvements in CCS } \\
\text { technologies }\end{array}$ \\
\hline
\end{tabular}




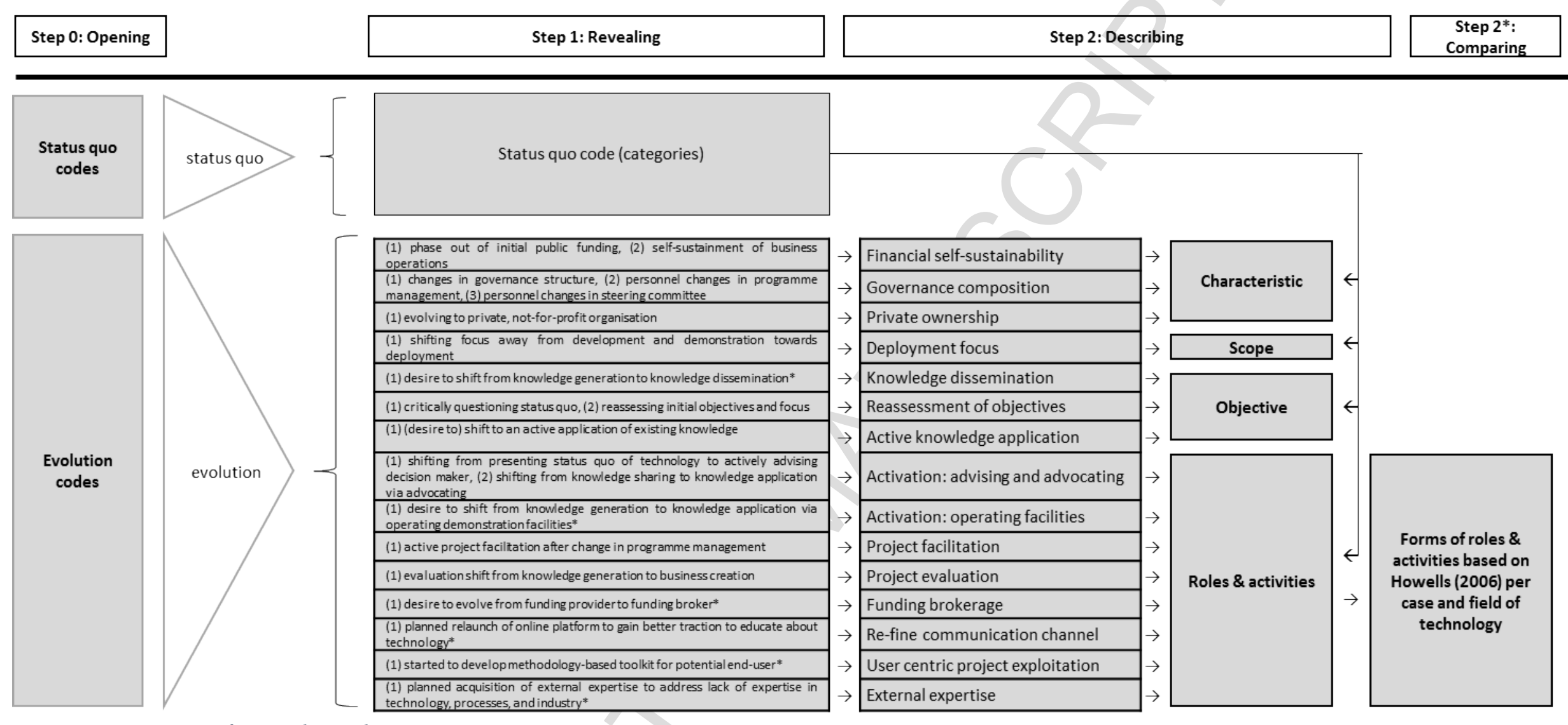

Figure 4: Data structure of intermediary's dynamics 


\begin{tabular}{|c|c|c|}
\hline \multirow{4}{*}{ Neutrality } & \multirow{3}{*}{$\begin{array}{l}\leftarrow \\
\leftarrow \\
\leftarrow\end{array}$} & Intervention by government \\
\hline & & Funding sources \\
\hline & & Objectivity \\
\hline & $\leftarrow$ & Top-down change \\
\hline \multirow{5}{*}{$\begin{array}{l}\text { Technological } \\
\text { context }\end{array}$} & \multirow{5}{*}{$\begin{array}{l}\stackrel{\leftarrow}{\leftarrow} \\
\leftarrow \\
\leftarrow \\
\leftarrow\end{array}$} & Proximity to technology \\
\hline & & Technology potential \\
\hline & & Functioning markets \\
\hline & & Policy support \\
\hline & & Technology development \\
\hline \multirow{5}{*}{$\begin{array}{c}\text { Shared } \\
\text { consensus }\end{array}$} & \multirow{5}{*}{$\begin{array}{l}\leftarrow \\
\leftarrow \\
\leftarrow \\
\leftarrow \\
\leftarrow\end{array}$} & Multi-stakeholder relationship \\
\hline & & Buy-in of partner \\
\hline & & Partner alignment \\
\hline & & Partner mix \\
\hline & & Expectation management \\
\hline \multirow{9}{*}{$\begin{array}{l}\text { Internal value } \\
\text { creation }\end{array}$} & \multirow{2}{*}{$\begin{array}{l}\leftarrow \\
\leftarrow\end{array}$} & Size of funding \\
\hline & & Vertical integration \\
\hline & \multirow{3}{*}{$\begin{array}{l}\leftarrow \\
\leftarrow \\
\leftarrow\end{array}$} & Complementary activities and relationships \\
\hline & & Competencies and knowledge \\
\hline & & Leadership \\
\hline & $\leftarrow$ & (Self-)organisation and management \\
\hline & \multirow{2}{*}{$\begin{array}{l}\leftarrow \\
\leftarrow\end{array}$} & Exploitation management \\
\hline & & Enlightenment \\
\hline & $\leftarrow$ & Communication and involvement \\
\hline
\end{tabular}

(1) address market failure, (2) counteract the financial crisis, (3) reporting obligations, (4) decision-making constraints, (5) short, 4-5 vears legislature withunknown outcome of upcoming elections, (6) membership feels uneasy due to constraints and volatility entitles for public funding, (4) ensure sustainment of business operationsvia ownership

(1) board members beyond membership, (2) board members based on required skills and experience, (3) independent board, (4) lack of objectivity in strategic decision making, (5) potential conflict of personal interest, (6) evidence-based decision making, (7) extermal experts advise governance structure, (8) narrowtechnology focus, (9) loosing big picture, (10) inabillty to advocate

introduction of to operate on a timescale as near-term as possible in a field of technology weth long development times, (2) top-down

(1) hands-oninteraction with technology

(1) keeping key indugtries in Europe, (2) turning a waste into aresource, (3) international agreements favour technology

(1) keping keynd (2) sutobe, (2) turningawastein to aresare

(1) (1) ETS not in favour of technology, (2) dependency on prices, (3) room for interpretation in na

(1) lack of government representation in triple helix approach, (2) collaboration of policy, technology, and market is key

5) partner assembly to bring community together, (6) release members from liabillty during capital-intensive projects workshop to settechnology focus

1) mix of partner limits (introduced) evolution, (2) narrow membership leads to inability to adequately represent opinion

(1) unclear contribution of intermediary and its partners, (2) partners do not take part in exploitation of technology, (3) partner expect

ongoing funding (unfulfilled), (4) partner expectationsdiverge

(1) discrepancy in available funding supply and R\&D demand, (2) lack of funding to incentives new partners

(3) knowledge network, (4) desire to collaborate aloneside the value chain to complement competencies, (3) reach out to various actors in the

(1) pre-determination of organisations niche/scope by existing competencies, (2) lack of understanding of technology (potential), processes, and industry, (3) underdevelopment of methodologiesto accesstechnologies, (4) lack of policy understanding for advocacy

1) failed to become a thought leader, (2) lack of self-organisation to secure external/additional funding, (3) untapped potential to use/share
(a) one partner's existing infrastructure, (4) ongoing strategic (re-Jalignment leaves little room for (bottom-up) decision making on the organisation's level, (5) difficulties in operationalising synergetic effects between projects, (6) need to showcase that new KPIs are met at the (1)

(2) lack of time to exploit project outcomes, (3) no formal technology transfer, (4) lack (5) IP with partners not intermediary, (6) openness of innovation is limited by partners' attitude towards competition
(1) create awareness and educate to overcome fear, (2) education is key, (3) lack of industry-wide standards to understand effectiveness of technology for decision making

(1) communicate to non-technical budget owner to increase understanding about technology, (2) involvement of end customer, (3) lack of

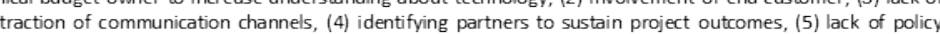
Figure 5: Data structure of intermediary's survival interaction, (6) underperformance of actionable recommendation 


\begin{tabular}{|c|c|c|c|c|c|}
\hline $\begin{array}{l}\text { Survival } \\
\text { Dimension }\end{array}$ & Code Theme & Code (Categories) & Quote & $\begin{array}{l}\text { Quote } \\
\#\end{array}$ & $\begin{array}{l}\text { Case } \\
\text { Reference }\end{array}$ \\
\hline Neutrality & $\begin{array}{l}\text { Intervention by } \\
\text { government }\end{array}$ & $\begin{array}{l}\text { membership feels uneasy due } \\
\text { to constraints and volatility }\end{array}$ & $\begin{array}{l}\text { "Our people [members] became aware of that all around the world and as } \\
\text { we were starting to talk about our future they felt our future was in doubts. } \\
\text { That was something we needed to deal with." }\end{array}$ & 1.1 & Case 3 \\
\hline Neutrality & Funding sources & $\begin{array}{l}\text { ensure sustainment of business } \\
\text { operations via ownership }\end{array}$ & $\begin{array}{l}\text { "Moving from a [PPP] model to a competitive and sustainable business in } \\
\text { the longer term, [case 4] reviewed and simplified the Constitution and } \\
\text { Members' Agreement. For the business to seek a broader range of } \\
\text { opportunities both domestically and internationally it was crucial that these } \\
\text { changes reflected our company status and structure." }\end{array}$ & 1.2 & Case 4 \\
\hline Neutrality & Funding sources & $\begin{array}{l}\text { organisations legal entity } \\
\text { entitles for public funding }\end{array}$ & $\begin{array}{l}\text { "The reason that we set it up as non-profit is to enable public money to come } \\
\text { in." }\end{array}$ & 1.3 & $\begin{array}{l}\text { Case } 2, \\
\text { Interviewee } \\
2\end{array}$ \\
\hline Neutrality & Objectivity & $\begin{array}{l}\text { evidence-based } \\
\text { making }\end{array}$ & $\begin{array}{l}\text { "We don't have any preconceptions, as a board member I don't have any } \\
\text { preconceptions, I don't have any biases towards any particular technology. } \\
\text { But I do like to see is an evidence-based case whether a technology should } \\
\text { be considered." }\end{array}$ & 1.4 & $\begin{array}{l}\text { Case 2, } \\
\text { Interviewee } \\
1, \text { Advisory } \\
\text { Board }\end{array}$ \\
\hline Neutrality & Objectivity & $\begin{array}{l}\text { evidence-based } \\
\text { making }\end{array}$ & $\begin{array}{l}\text { "It is not our role to pick winners in there [the field of technology], in fact } \\
\text { this is a poor way to go." }\end{array}$ & 1.5 & Case 3 \\
\hline Neutrality & Objectivity & inability to advocate & $\begin{array}{l}\text { "Talking to policy makers at that time with the representation of only one } \\
\text { industry stakeholder and twelve academic partners raises the question how } \\
\text { heardyou are and how valid is the opinion that you are representing in terms } \\
\text { of advocacy to policy makers, who usually look for bigger representation of } \\
\text { opinions." }\end{array}$ & 1.6 & $\begin{array}{l}\text { Case } 1, \\
\text { Interviewee } \\
2, \quad \text { Lead } \\
\text { partner } 1\end{array}$ \\
\hline Neutrality & Top-down change & fluctuation of personnel & $\begin{array}{l}\text { "[...] I just jumped in to something that was already there and tried to figure } \\
\text { out how to create value for [lead partner 1]." }\end{array}$ & 1.7 & $\begin{array}{l}\text { Case } 1, \\
\text { Interviewee } \\
2, \quad \text { Lead } \\
\text { partner } 1\end{array}$ \\
\hline Neutrality & Top-down change & $\begin{array}{l}\text { requirement to operate on a } \\
\text { timescale as near-term as } \\
\text { possible in a field of } \\
\text { technology with long } \\
\text { development times }\end{array}$ & $\begin{array}{l}\text { "[...] our desire to operate on a timescale as near-term as short-term as } \\
\text { possible. That is [the reason for the narrow technology focus]" } \\
\text { "[...] what kind of return we are having on the climate, a lot of that is way } \\
\text { out in the future. That's tough. We need impact on a shorter time horizon." }\end{array}$ & 1.8 & $\begin{array}{l}\text { Case } \quad 1, \\
\text { Interviewee } \\
1, \quad \text { Lead } \\
\text { partner } 1\end{array}$ \\
\hline Neutrality & Top-down change & $\begin{array}{l}\text { de-prioritisation of governance } \\
\text { re-structure }\end{array}$ & $\begin{array}{l}\text { "[...] the steering committee, probably, was de-prioritised by us in terms of } \\
\text { not being the most essential thing, where we wanted to work on together with } \\
\text { [lead partner 2]. It was more on the metrics and the value for [lead partner }\end{array}$ & 1.9 & $\begin{array}{l}\text { Case 1, } \\
\text { Interviewee }\end{array}$ \\
\hline
\end{tabular}


$1]$ and understanding the success and measure the success of the [programme]. That is probably why we de-prioritised the governance."

\begin{tabular}{llll}
\hline $\begin{array}{l}\text { Technological } \\
\text { context }\end{array}$ & $\begin{array}{l}\text { Technology } \\
\text { potential }\end{array}$ & keeping key industries in \\
Europe
\end{tabular}

"There are these competing viewpoints: on the one hand [CO $\mathrm{C}_{2}$ utilisation] is this incredible technology that's chemically and from an energy perspective more efficient than photosynthesis and that has the potential to be carbon negative and replace fossil resources in important materials like plastics and chemicals. And it is also from an industrial standpoint an interesting way to keep key industries - like chemicals, like steel making, like cement - in Europe, because without some sort of $\mathrm{CO}_{2}$ capture those industries will have to leave Europe."

Technological Policy support dependency on prices context

Technological Policy support context

effective integration

executive authorities

"On the other hand, [CO $\mathrm{CO}_{2}$ utilisation] is a technology that really plays on the margins, doesn't have the volumes that CCS has. Its existence is really dependent on some bigger things like the price of petroleum and the price of carbon."

of

"The challenges we tend to see would be more around where you don't have an effective either integration or coordination between DGs in the case of the Commission, but departments or ministries in other parts of the world. If you don't get a sensible connection between environment policy and energy policy that is when you start getting the problems."

\begin{tabular}{|c|c|c|c|c|c|}
\hline $\begin{array}{l}\text { Technological } \\
\text { context }\end{array}$ & $\begin{array}{l}\text { Technology } \\
\text { development }\end{array}$ & high project failure rates & $\begin{array}{l}\text { "If you are talking to a company, which is a very good company [...] 97\% } \\
\text { of their projects die, they don't make it to the market. And these are guys, } \\
\text { who know their stuff." }\end{array}$ & 2.5 & $\begin{array}{l}\text { Case } 2, \\
\text { Interviewee } \\
2\end{array}$ \\
\hline $\begin{array}{l}\text { Shared } \\
\text { consensus }\end{array}$ & Buy-in of partner & $\begin{array}{l}\text { lack of a shared vision, } \\
\text { inability to create team spirit }\end{array}$ & $\begin{array}{l}\text { "There was no vision. There was no 'what we want to push with this thing?'. } \\
\text { There were objectives, like you said, but the vision and why we are all } \\
\text { combined, why we are all together: the glue of the team was missing. We } \\
\text { were not a team. That is what I am learning in these public funded projects. } \\
\text { It is difficult to create a team spirit." }\end{array}$ & 3.1 & $\begin{array}{l}\text { Case } \quad 1, \\
\text { Interviewee } \\
2, \quad \text { Lead } \\
\text { partner } 1\end{array}$ \\
\hline $\begin{array}{l}\text { Shared } \\
\text { consensus }\end{array}$ & Buy-in of partner & $\begin{array}{l}\text { partner assembly to bring } \\
\text { community together }\end{array}$ & $\begin{array}{l}\text { "[...] this changed with [interviewee 1] joining - so that the project would } \\
\text { be aware of the other projects and there could be ideally synergies created } \\
\text { between the projects." }\end{array}$ & 3.2 & $\begin{array}{l}\text { Case } \quad 1, \\
\text { Interviewee } \\
2, \quad \text { Lead } \\
\text { partner 1 }\end{array}$ \\
\hline $\begin{array}{l}\text { Shared } \\
\text { consensus }\end{array}$ & Partner alignment & $\begin{array}{l}\text { inability to group and apply for } \\
\text { external funding }\end{array}$ & $\begin{array}{l}\text { "[...] we were never able to group ourselves as a group and do something } \\
\text { together to go for bigger funding." }\end{array}$ & 3.3 & $\begin{array}{l}\text { Case } \quad 1, \\
\text { Interviewee } \\
2, \quad \text { Lead } \\
\text { partner } 1\end{array}$ \\
\hline
\end{tabular}




\begin{tabular}{|c|c|c|c|c|c|}
\hline $\begin{array}{l}\text { Shared } \\
\text { consensus }\end{array}$ & Partner mix & $\begin{array}{l}\text { mix of partner limits } \\
\text { (introduced) evolution }\end{array}$ & $\begin{array}{l}\text { "One of the things that [the funder] is most concerned about, most interested } \\
\text { in is new business creation. One of the things that become clear over the last } \\
12-18 \text { month is that the path towards new business creation in the [CO } \\
\text { utilisation] space is - at least given our current partner mix - pretty limited. } \\
\text { [...] That was one of the considerations in looking at why the next phase } \\
\text { didn't happen." }\end{array}$ & 3.4 & $\begin{array}{l}\text { Case } 1, \\
\text { Interviewee } \\
1, \quad \text { Lead } \\
\text { partner } 1\end{array}$ \\
\hline $\begin{array}{l}\text { Shared } \\
\text { consensus }\end{array}$ & $\begin{array}{l}\text { Expectation } \\
\text { management }\end{array}$ & $\begin{array}{l}\text { unclear contribution of } \\
\text { intermediary and its partners }\end{array}$ & $\begin{array}{l}\text { "[...] we needed to look at the more long-term objectives and we started to } \\
\text { ask ourselves: what is the added value to this whole discussion; how can we } \\
\text { serve the partners right; and what we can get back from the partners." }\end{array}$ & 3.5 & $\begin{array}{l}\text { Case } \quad 1, \\
\text { Interviewee } \\
2, \quad \text { Lead } \\
\text { partner } 1\end{array}$ \\
\hline $\begin{array}{l}\text { Shared } \\
\text { consensus }\end{array}$ & $\begin{array}{l}\text { Expectation } \\
\text { management }\end{array}$ & $\begin{array}{l}\text { partner expect ongoing } \\
\text { funding (unfulfilled) }\end{array}$ & $\begin{array}{l}\text { "[...] that was where it was difficult to match partner wishes and our } \\
\text { requirement of becoming self-sustainable" } \\
\text { "[...] the research colleagues had their wishes that suddenly - due to the } \\
\text { repositioning - were not fulfilled anymore." }\end{array}$ & 3.6 & $\begin{array}{l}\text { Case } 1, \\
\text { Interviewee } \\
2, \quad \text { Lead } \\
\text { partner } 1\end{array}$ \\
\hline $\begin{array}{l}\text { Internal value } \\
\text { creation }\end{array}$ & Size of funding & $\begin{array}{l}\text { discrepancy in available } \\
\text { funding supply and R\&D } \\
\text { demand }\end{array}$ & $\begin{array}{l}\text { "[The] programme has - what we consider at [lead partner 1]- a significant } \\
\text { amount of funding in total. But if we relate that to what is necessary to } \\
\text { develop, to commercialise technologies in the chemical industry or the } \\
\text { materials industry where }\left[\mathrm{CO}_{2} \text { utilisation] is used, it's a rounding error }\right. \\
\text { compared the many many millions that are needed to take something from } \\
\text { even a high level of technological development in the laboratory and scale } \\
\text { it up to pilot or industrial/commercial scale." }\end{array}$ & 4.1 & $\begin{array}{l}\text { Case } 1, \\
\text { Interviewee } \\
1, \quad \text { Lead } \\
\text { partner } 1\end{array}$ \\
\hline $\begin{array}{l}\text { Internal value } \\
\text { creation }\end{array}$ & $\begin{array}{l}\text { Vertical } \\
\text { integration }\end{array}$ & $\begin{array}{l}\text { capture more value by } \\
\text { operating } \\
\text { research/demonstration } \\
\text { outcomes/facilities in the } \\
\text { future }\end{array}$ & $\begin{array}{l}\text { "We envisage a transition from a pure research organisation to an } \\
\text { organisation that - given our experience - is more and more moving the } \\
\text { actual operation of CCS projects as they potentially come off line." }\end{array}$ & 4.2 & Case 4 \\
\hline $\begin{array}{l}\text { Internal value } \\
\text { creation }\end{array}$ & $\begin{array}{l}\text { Complementary } \\
\text { activities and } \\
\text { relationships }\end{array}$ & $\begin{array}{l}\text { complementing } \begin{array}{r}\text { close } \\
\text { relationship to another } \\
\text { intermediary }\end{array}\end{array}$ & $\begin{array}{l}\text { "I see the two organisations as complementary. We have obviously pretty } \\
\text { close relationship, because I know most the senior people there and they } \\
\text { know us, and they are members of ours and we have given them money. } \\
\text { Pretty obviously it is a comfortable relationship. But we are different. They } \\
\text { employ almost exclusively scientists and I almost exclusively don't employ } \\
\text { scientist. That is how it works." }\end{array}$ & 4.3 & Case 3 \\
\hline $\begin{array}{l}\text { Internal value } \\
\text { creation }\end{array}$ & $\begin{array}{l}\text { Competencies and } \\
\text { knowledge }\end{array}$ & $\begin{array}{l}\text { lack of understanding of } \\
\text { technology (potential), } \\
\text { processes, and industry }\end{array}$ & $\begin{array}{l}\text { "We realised too late that we need somebody external, unbiased, that would } \\
\text { help [the lead partner 1] to understand the technical part of it." }\end{array}$ & 4.4 & $\begin{array}{l}\text { Case 1, } \\
\text { Interviewee } \\
2, \quad \text { Lead } \\
\text { partner } 1\end{array}$ \\
\hline $\begin{array}{l}\text { Internal value } \\
\text { creation }\end{array}$ & $\begin{array}{l}\text { (Self-)organisation } \\
\text { and management }\end{array}$ & $\begin{array}{l}\text { failed to become a thought } \\
\text { leader }\end{array}$ & $\begin{array}{l}\text { "We never thought of organising ourselves. There is that }\left[\mathrm{CO}_{2} \text { utilisation] }\right. \\
\text { conference, but we never came up with the idea why don't we present yearly }\end{array}$ & 4.5 & $\begin{array}{l}\text { Case 1, } \\
\text { Interviewee }\end{array}$ \\
\hline
\end{tabular}


the newest results that are coming out from all the studies, the systemic studies there. The though leadership piece was definitely missing."

Internal value (Self-)organisation need to showcase that new creation and management

KPIs are met at the expense of

ongoing knowledge generation

knowledge transfer and knowledge adoption. That KPI doesn't exist anymore. That makes pure research projects pretty tough. [...] Projects that happen essentially in the laboratory or at someone's desk. We get less credit from our funder for those kinds of activities. That is one of the reasons we are at this point: we are re-evaluating how we engage on the topic."

\begin{tabular}{|c|c|c|c|c|c|}
\hline $\begin{array}{l}\text { Internal value } \\
\text { creation }\end{array}$ & $\begin{array}{l}\text { Exploitation } \\
\text { management }\end{array}$ & $\begin{array}{l}\text { lack of product } \\
\text { manager/developer } \\
\text { organisation or initiative }\end{array}$ & $\begin{array}{l}\text { "I think we lack a product developer in the team. [...] Somebody that } \\
\text { recognises there is a value [in the project outcomes]. Maybe also together } \\
\text { with the research universities. Let's build this as a service. Why did we never } \\
\text { think about that? Honestly, we didn't have the time." }\end{array}$ & 4.7 & $\begin{array}{l}\text { Case } \quad 1, \\
\text { Interviewee } \\
2, \quad \text { Lead } \\
\text { partner 1 }\end{array}$ \\
\hline $\begin{array}{l}\text { Internal value } \\
\text { creation }\end{array}$ & $\begin{array}{l}\text { Communication } \\
\text { and involvement }\end{array}$ & $\begin{array}{l}\text { identifying partners to sustain } \\
\text { project outcomes }\end{array}$ & $\begin{array}{l}\text { "That is a key topic for us right now: figuring out who we can partner with, } \\
\text { how we - in some ways - can pass the torch on some of our work and make } \\
\text { sure that the knowledge is shared more broadly." }\end{array}$ & 4.8 & $\begin{array}{l}\text { Case } 1, \\
\text { Interviewee } \\
1, \quad \text { Lead } \\
\text { partner 1 }\end{array}$ \\
\hline $\begin{array}{l}\text { Internal value } \\
\text { creation }\end{array}$ & $\begin{array}{l}\text { Communication } \\
\text { and involvement }\end{array}$ & involvement of end customer & $\begin{array}{l}\text { "One of the things we are doing in the next [programmes] is have toolkits } \\
\text { that we can sell to different cities and regions that they would pay for and } \\
\text { ultimately, we can cover some of the cost if not make some revenue." }\end{array}$ & 4.9 & $\begin{array}{l}\text { Case } \quad 1, \\
\text { Interviewee } \\
1, \quad \text { Lead } \\
\text { partner 1 }\end{array}$ \\
\hline
\end{tabular}

Table 5: Overview of roles and activities of innovation intermediaries in study (Adapted from Howells, 2006

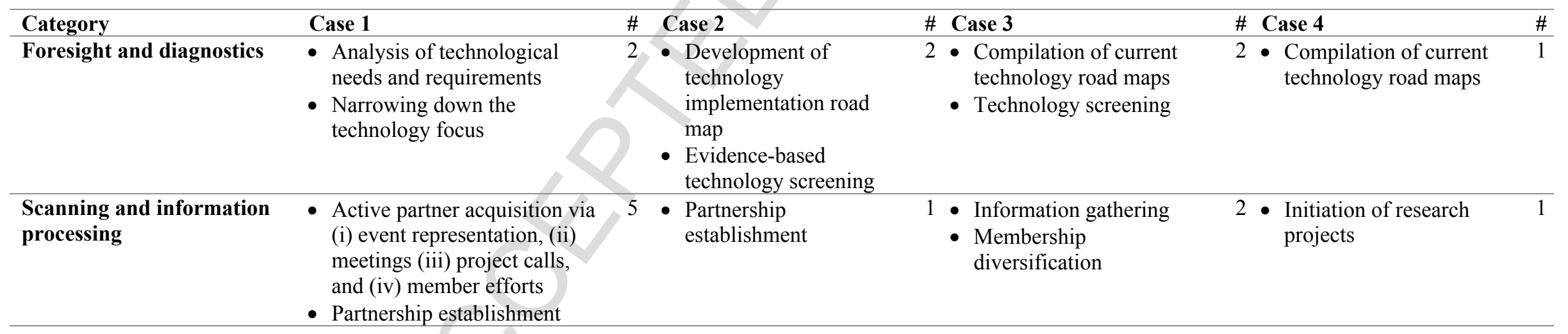




\begin{tabular}{|c|c|c|c|c|c|c|c|c|}
\hline $\begin{array}{l}\text { Knowledge processing, } \\
\text { generation and } \\
\text { combination/recombination }\end{array}$ & $\begin{array}{l}\text { - Innovation projects: outcomes } \\
\text { and dissemination } \\
\text { - Partner assemblies } \\
\text { - Online platforms } \\
\text { - Networks }\end{array}$ & 4 & $\begin{array}{l}\text { - Contract research } \\
\text { - Online and offline } \\
\text { dissemination of } \\
\text { finding }\end{array}$ & & $\begin{array}{l}\text { - Compilation of } \\
\text { knowledge } \\
\text { - Online and offline } \\
\text { dissemination of finding }\end{array}$ & 3 & $\begin{array}{l}\text { - Online and offline } \\
\text { dissemination of finding }\end{array}$ & 2 \\
\hline Gatekeeping and brokering & $\begin{array}{l}\text { - Value chain matchmaking } \\
\text { - Provision of a grant } \\
\text { agreement }\end{array}$ & 2 & $\begin{array}{l}\text { - Information provision } \\
\text { about contracts }\end{array}$ & 1 & $\begin{array}{l}\text { - Information provision } \\
\text { about contracts } \\
\text { - Prepare agreements } \\
\text { - Finance negotiations }\end{array}$ & 3 & $\begin{array}{l}\text { - Manage collaboration } \\
\text { agreements } \\
\text { - Value chain } \\
\text { matchmaking } \\
\text { - Provision of a } \\
\text { project/membership } \\
\text { agreement } \\
\text { - Agreement negotiations } \\
\text { - Contracting services }\end{array}$ & 5 \\
\hline $\begin{array}{l}\text { Testing, validation and } \\
\text { training }\end{array}$ & $\begin{array}{l}\text { - Technology development } \\
\text { projects } \\
\text { - Hackathon project activity } \\
\text { - Provision of partner's testing } \\
\text { facility } \\
\text { - Provision of partner's training }\end{array}$ & 4 & $\begin{array}{l}\text { - Development of } \\
\text { investment thesis }\end{array}$ & 1 & & 0 & $\begin{array}{l}\text { Project-based technology } \\
\text { development to (i) } \\
\text { validate, (ii) demonstrate } \\
\text { safe operations, (iii) pilot } \\
\text { applications, and (iv) } \\
\text { build research portfolio } \\
\text { - Training services }\end{array}$ & 6 \\
\hline $\begin{array}{l}\text { Accreditation and } \\
\text { standards }\end{array}$ & $\begin{array}{l}\text { - Development of LCA/TEA } \\
\text { guideline }\end{array}$ & 1 & $\begin{array}{l}\text { - Development of } \\
\text { LCA/TEA guideline } \\
\text { - Application of } \\
\text { standards in technology } \\
\text { screening }\end{array}$ & 2 & $\begin{array}{l}\text { - Information provision } \\
\text { about standards } \\
\text { - Provision of best-practice } \\
\text { guidelines } \\
\text { - Advocacy for standards }\end{array}$ & 3 & $\begin{array}{l}\text { - Advocacy for } \\
\text { standardisation } \\
\text { - Adapting best practice in } \\
\text { operations }\end{array}$ & 3 \\
\hline $\begin{array}{l}\text { Validation and regulation } \\
\text { and arbitration }\end{array}$ & $\begin{array}{l}\text { - Social acceptance studies } \\
\text { - Scenario-based policy studies } \\
\text { - Reports to create awareness } \\
\text { - Early stage dialogue with } \\
\text { policy makers }\end{array}$ & & $\begin{array}{l}\text { - } \text { Building a rapport to } \\
\text { policy/decision makers } \\
\text { - Advocacy }\end{array}$ & 2 & $\begin{array}{l}\text { - Dialogue with policy } \\
\text { makers on various topics } \\
\text { - Execution of } \\
\text { communication and } \\
\text { advocacy strategy }\end{array}$ & 6 & $\begin{array}{l}\text { - Negotiating/liaising } \\
\text { regulations } \\
\text { - Community engagement }\end{array}$ & 2 \\
\hline $\begin{array}{l}\text { Intellectual property: } \\
\text { Protecting the results }\end{array}$ & - Provision of grant agreement & 1 & & 0 & & & $\begin{array}{l}\text { - IP assessment } \\
\text { - IP management } \\
\text { - IP ownership } \\
\text { - Information provision } \\
\text { about patenting }\end{array}$ & 4 \\
\hline
\end{tabular}


Commercialisation:

exploitation the outcomes

- Development of market

understanding

Assessment and Evaluation

of outcomes

- Techno-economic and

environmental assessments

- Project evaluation

\#: number of reported codes per category
- Deployment analysis and

strategies

- Environmental

1 - Economic analyses assessments

$+$

1 - Market research

- IP exploitation via

patenting

- Techno-economic

analyses

- Strategic planning 
Assessment and Evaluation of outcomes

Commercialisation: exploitation the outcomes

Intellectual property: Protecting the results

Validation and regulation and arbitration

Accreditation and standards

Testing, validation and training

Gatekeeping and brokering

Knowledge..

Scanning and information processing

Foresight and diagnostics

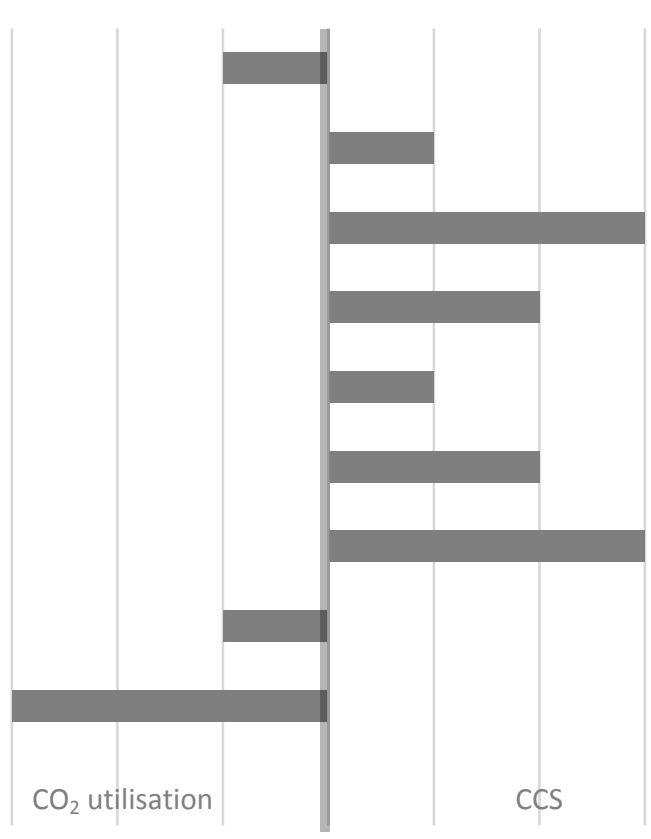

$-4 \quad-3$

$-2 \quad-1$

0

3

Subtraction of the max. \# of reported codes in $\mathrm{CO}_{2}$ utilisation from the max. \# of reported codes in CCS

Figure 6: Role and activity comparison (based on Howells, 2006) per field of technology 


\section{References}

Akintoye, A., Beck, M., Hardcastle, C., 2008. Public-private partnerships. Managing risks and opportunities. John Wiley \& Sons.

Aresta, M., Dibenedetto, A., Angelini, A., 2013. The changing paradigm in CO2 utilization. Journal of CO2 Utilization 3-4, 65-73.

ATLAS.ti, 2018. ATLAS.ti: The Qualitative Data Analysis \& Research Software. http://atlasti.com/. Accessed 13/02/18.

Augier, M., Teece, D.J., 2008. Strategy as Evolution with Design. The Foundations of Dynamic Capabilities and the Role of Managers in the Economic System. Organization Studies 29, 1187-1208.

Barrie, J., Zawdie, G., João, E., 2017. Leveraging triple helix and system intermediaries to enhance effectiveness of protected spaces and strategic niche management for transitioning to circular economy. International Journal of Technology Management \& Sustainable Development 16, 25-47.

Bergek, A., Hekkert, M., Jacobsson, S., Markard, J., Sandén, B., Truffer, B., 2015. Technological innovation systems in contexts. Conceptualizing contextual structures and interaction dynamics. Environmental Innovation and Societal Transitions 16, 51-64.

Bergek, A., Jacobsson, S., Carlsson, B., Lindmark, S., Rickne, A., 2008. Analyzing the functional dynamics of technological innovation systems. A scheme of analysis. Research Policy 37, 407-429.

Bessant, J., Rush, H., 1995. Building bridges for innovation. The role of consultants in technology transfer. Research Policy 24, 97-114.

Binz, C., Truffer, B., 2017. Global Innovation Systems-A conceptual framework for innovation dynamics in transnational contexts. Research Policy 46, 1284-1298.

Bleda, M., del Río, P., 2013. The market failure and the systemic failure rationales in technological innovation systems. Research Policy 42, 1039-1052.

Bocken, N.M.P., Short, S.W., Rana, P., Evans, S., 2014. A literature and practice review to develop sustainable business model archetypes. Journal of Cleaner Production 65, 42-56.

Boon, W.P.C., Moors, E.H.M., Kuhlmann, S., Smits, R.E.H.M., 2011. Demand articulation in emerging technologies. Intermediary user organisations as co-producers? Research Policy 40, 242-252.

Boons, F., Lüdeke-Freund, F., 2013. Business models for sustainable innovation: state-of-theart and steps towards a research agenda. Journal of Cleaner Production 45, 9-19.

Bui, M., Adjiman, C.S., Bardow, A., Anthony, E.J., Boston, A., Brown, S., Fennell, P.S., Fuss, S., Galindo, A., Hackett, L.A., Hallett, J.P., Herzog, H.J., Jackson, G., Kemper, J., Krevor, S., Maitland, G.C., Matuszewski, M., Metcalfe, I.S., Petit, C., Puxty, G., Reimer, J., Reiner, D.M., Rubin, E.S., Scott, S.A., Shah, N., Smit, B., Trusler, J.P.M., Webley, P., Wilcox, J., Mac Dowell, N., 2018. Carbon capture and storage (CCS). The way forward. Energy Environ. Sci. 3, 1645.

Coninck, H. de, Stephens, J.C., Metz, B., 2009. Global learning on carbon capture and storage. A call for strong international cooperation on CCS demonstration. Energy Policy 37, 21612165.

Dütschke, E., Wohlfarth, K., Höller, S., Viebahn, P., Schumann, D., Pietzner, K., 2016. Differences in the public perception of CCS in Germany depending on CO 2 source, transport option and storage location. International Journal of Greenhouse Gas Control 53, 149-159. 
Eisenhardt, K.M., 1989. Building theories from case study research. Academy of management review 14, 532-550.

Eisenhardt, K.M., Graebner, M.E., 2007. Theory Building from Cases: Opportunities and Challenges. The Academy of Management Journal 50, 25-32.

Eisenhardt, K.M., Martin, J.A., 2000. Dynamic capabilities: What are they? Strategic Management Journal; 21, 1105-1121.

Expósito-Langa, M., Molina-Morales, F.X., Tomás-Miquel, J.-V., 2015. How shared vision moderates the effects of absorptive capacity and networking on clustered firms' innovation. Scandinavian Journal of Management 31, 293-302.

Geels, F., Deuten, J.J., 2006. Local and global dynamics in technological development. A sociocognitive perspective on knowledge flows and lessons from reinforced concrete. sci public policy 33, 265-275.

Geels, F.W., 2011. The multi-level perspective on sustainability transitions: Responses to seven criticisms. Environmental Innovation and Societal Transitions 1, 24-40.

Gioia, D.A., Corley, K.G., Hamilton, A.L., 2013. Seeking Qualitative Rigor in Inductive Research. Organizational Research Methods 16, 15-31.

Gliedt, T., Hoicka, C.E., Jackson, N., 2018. Innovation intermediaries accelerating environmental sustainability transitions. Journal of Cleaner Production 174, 1247-1261.

Grin, J., Rotmans, J., Schot, J., 2010. Transitions to sustainable development. New directions in the study of long term transformative change. Routledge.

Hahn, R., Ince, I., 2016. Constituents and Characteristics of Hybrid Businesses: A Qualitative, Empirical Framework. Journal of Small Business Management 54, 33-52.

Hakkarainen, L., Hyysalo, S., 2016. The evolution of intermediary activities. Broadening the concept of facilitation in living labs. Technology Innovation Management Review 6.

Hockerts, K., Wüstenhagen, R., 2010. Greening Goliaths versus emerging Davids - Theorizing about the role of incumbents and new entrants in sustainable entrepreneurship. Journal of Business Venturing 25, 481-492.

Hodge, G.A., Greve, C., Boardman, A., 2010. International handbook on public-private partnerships. Edward Elgar Publishing.

Hodson, M., Marvin, S., 2010. Can cities shape socio-technical transitions and how would we know if they were? Research Policy 39, 477-485.

Hörisch, J., 2015. The Role of Sustainable Entrepreneurship in Sustainability Transitions: A Conceptual Synthesis against the Background of the Multi-Level Perspective. Administrative Sciences 5, 286-300.

Howells, J., 2006. Intermediation and the role of intermediaries in innovation. Research Policy $35,715-728$.

Jones, C.R., Olfe-Kräutlein, B., Naims, H., Armstrong, K., 2017. The Social Acceptance of Carbon Dioxide Utilisation. A Review and Research Agenda. Front. Energy Res. 5, 3.

Kanda, W., 2017. Stimulating the diffusion of environmental technologies through export. Linköping University Electronic Press, Linköping.

Kanda, W., Clausen, J., Hjelm, O., Bienkowska, D., 2015. Functions of intermediaries in ecoinnovation. A study of business development organizations and cluster initiatives in a Swedish and a German region. Presented at the Global Cleaner Production and Sustainable Consumption Conference, 1-4 November, Sitges-Barcelona,Spain.

Kanda, W., Hjelm, O., Clausen, J., Bienkowska, D., 2018. Roles of intermediaries in supporting eco-innovation. Journal of Cleaner Production 205, 1006-1016. 
Kanda, W., Sakao, T., Hjelm, O., 2016. Components of business concepts for the diffusion of large scaled environmental technology systems. Journal of Cleaner Production 128, 156167.

Kant, M., 2017. Overcoming Barriers to Successfully Commercializing Carbon Dioxide Utilization. Front. Energy Res. 5, 14.

Kilelu, C.W., Klerkx, L., Leeuwis, C., Hall, A., 2011. Beyond knowledge brokering. An exploratory study on innovation intermediaries in an evolving smallholder agricultural system in Kenya. Knowledge Management for Development Journal 7, 84-108.

Kivimaa, P., 2014. Government-affiliated intermediary organisations as actors in system-level transitions. Research Policy 43, 1370-1380.

Kivimaa, P., Boon, W., Hyysalo, S., Klerkx, L., 2019a. Towards a typology of intermediaries in sustainability transitions. A systematic review and a research agenda. Research Policy 48 , 1062-1075.

Kivimaa, P., Hyysalo, S., Boon, W., Klerkx, L., Martiskainen, M., Schot, J., 2019b. Passing the baton. How intermediaries advance sustainability transitions in different phases. Environmental Innovation and Societal Transitions.

Kivimaa, P., Martiskainen, M., 2018. Dynamics of policy change and intermediation. The arduous transition towards low-energy homes in the United Kingdom. Energy Research \& Social Science 44, 83-99.

Klerkx, L., Leeuwis, C., 2009. Establishment and embedding of innovation brokers at different innovation system levels. Insights from the Dutch agricultural sector. Technological Forecasting and Social Change 76, 849-860.

Koppenjan, J.F.M., 2015. Public-Private Partnerships for green infrastructures. Tensions and challenges. Current Opinion in Environmental Sustainability 12, 30-34.

Kraeusel, J., Möst, D., 2012. Carbon Capture and Storage on its way to large-scale deployment. Social acceptance and willingness to pay in Germany. Energy Policy 49, 642-651.

Lukkarinen, J., Berg, A., Salo, M., Tainio, P., Alhola, K., Antikainen, R., 2018. An intermediary approach to technological innovation systems (TIS) - The case of the cleantech sector in Finland. Environmental Innovation and Societal Transitions 26, 136-146.

Markard, J., 2018. The life cycle of technological innovation systems. Technological Forecasting and Social Change.

Markard, J., Raven, R., Truffer, B., 2012. Sustainability transitions: An emerging field of research and its prospects. Research Policy 41, 955-967.

Markard, J., Truffer, B., 2008. Technological innovation systems and the multi-level perspective. Towards an integrated framework. Research Policy 37, 596-615.

Martiskainen, M., Kivimaa, P., 2018. Creating innovative zero carbon homes in the United Kingdom - Intermediaries and champions in building projects. Environmental Innovation and Societal Transitions 26, 15-31.

Matschoss, K., Heiskanen, E., 2017. Making it experimental in several ways. The work of intermediaries in raising the ambition level in local climate initiatives. Journal of Cleaner Production 169, 85-93.

Mignon, I., Kanda, W., 2018. A typology of intermediary organizations and their impact on sustainability transition policies. Environmental Innovation and Societal Transitions 29, 100-113.

Moss, T., 2009. Intermediaries and the Governance of Sociotechnical Networks in Transition. Environ Plan A 41, 1480-1495. 
Murphy, M., Arenas, D., Batista, J.M., 2015. Value Creation in Cross-Sector Collaborations. The Roles of Experience and Alignment. J Bus Ethics 130, 145-162.

Naims, H., 2016. Economics of carbon dioxide capture and utilization-a supply and demand perspective. Environmental science and pollution research international 23, 22226-22241.

Nauclér, T., Enkvist, P.-A., 2009. Pathways to a low-carbon economy. Version 2 of the global greenhouse gas abatement cost curve.

Nelson, R.R., Winter, S.G., 2009. An Evolutionary Theory of Economic Change. Harvard University Press, London, UK.

Pacheco, D.F., Dean, T.J., Payne, D.S., 2010. Escaping the green prison: Entrepreneurship and the creation of opportunities for sustainable development. Journal of Business Venturing 25, 464-480.

Palinkas, L.A., Horwitz, S.M., Green, C.A., Wisdom, J.P., Duan, N., Hoagwood, K., 2015. Purposeful Sampling for Qualitative Data Collection and Analysis in Mixed Method Implementation Research. Administration and policy in mental health 42, 533-544.

Parag, Y., Janda, K.B., 2014. More than filler. Middle actors and socio-technical change in the energy system from the "middle-out". Energy Research \& Social Science 3, 102-112.

Patton, M.Q., 2015. Qualitative evaluation and research methods:. integrating theory and practice, 4th. Sage, Los Angeles, CA, USA.

Peters, M., Schneider, M., Griesshaber, T., Hoffmann, V.H., 2012. The impact of technologypush and demand-pull policies on technical change - Does the locus of policies matter? Research Policy 41, 1296-1308.

Polzin, F., Flotow, P. von, Klerkx, L., 2016. Addressing barriers to eco-innovation. Exploring the finance mobilisation functions of institutional innovation intermediaries. Technological Forecasting and Social Change 103, 34-46.

Rumelt, R.P., 2011. Good strategy, bad strategy. The difference and why it matters, 1. ed. Crown Business, New York.

Silva, M. de, Howells, J., Meyer, M., 2018. Innovation intermediaries and collaboration. Knowledge-based practices and internal value creation. Research Policy 47, 70-87.

Stewart, J., Hyysalo, S., 2008. Intermediaries, users and social learning in technological innovation. Int. J. Innov. Mgt. 12, 295-325.

Strauss, A.L., Corbin, J.M., 2015. Basics of Qualitative Research. Techniques and Procedures for Developing Grounded Theory, 4th. Sage publications, Thousand Oaks, CA, USA.

Styring, P., Jansen, D., 2011. Carbon Capture and Utilisation in the green economy. Using CO2 to manufacture fuel, chemicals and materials. CO2Chem Publishing, Sheffield, UK.

Styring, P., Quadrelli, E.A., Armstrong, K. (Eds.), 2015. Carbon Dioxide Utilisation. Elsevier, Amsterdam.

Teece, D.J., 2007. Explicating dynamic capabilities. The nature and microfoundations of (sustainable) enterprise performance. Strat. Mgmt. J. 28, 1319-1350.

Teece, D.J., 2011. Achieving integration of the business school curriculum using the dynamic capabilities framework. Journal of Mgmt Development 30, 499-518.

Teece, D.J., 2018. Dynamic capabilities as (workable) management systems theory. Journal of Management \& Organization 24, 359-368.

Teece, D.J., Pisano, G., Shuen, A., 1997. Dynamic Capabilities and Strategic Management. Strategic Management Journal; 18, 509-533.

Timmermans, S., Tavory, I., 2012. Theory Construction in Qualitative Research: From Grounded Theory to Abductive Analysis. Sociological Theory 30, 167-186. 
Tjong Tjin Tai, S.-Y., Davids, M., 2016. Evolving roles and dynamic capabilities of an innovation agency. The Dutch Rijksnijverheidsdienst, 1910-1940. Technology Analysis \& Strategic Management 28, 614-626.

van Lente, H., Hekkert, M., Smits, R., van Waveren, B., 2003. Roles of Systemic Intermediaries in Transition Processes. Int. J. Innov. Mgt. 07, 247-279.

Yaqub, O., Nightingale, P., 2012. Vaccine innovation, translational research and the management of knowledge accumulation. Social science \& medicine (1982) 75, 21432150.

Yin, R.K., 2013. Case study research: Design and methods, 5th. Sage publications.

Zimmermann, A.W., Schomäcker, R., 2017. Assessing Early-Stage CO 2 utilization Technologies-Comparing Apples and Oranges? Energy Technol. 5, 850-860. 


\section{Annex}

Table 6: Overview of cases' evolution and survival [ANNEX]

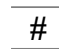

Code Themes

Financial self-sustainability

Code (Categories)
(1) phase out of initial

Governance composition

Private ownership

Deployment focus

Knowledge dissemination

Reassessment of objectives

Active knowledge application

Activation: advising and

advocating

Activation: operating facilities

Project facilitation

Project evaluation

Funding brokerage

Communication channel

User centric

exploitation

External expertise

\begin{tabular}{|c|c|c|c|c|}
\hline & & $\begin{array}{l}\text { User centric project } \\
\text { exploitation }\end{array}$ & (1) started to develop methodology-based toolkit for potential end-user* & Case $1 *$ \\
\hline & & External expertise & $\begin{array}{l}\text { (1) planned acquisition of external expertise to address lack of expertise in } \\
\text { technology, processes, and industry* }\end{array}$ & Case $1^{*}$ \\
\hline 1 & Neutrality & Intervention by govern & $\begin{array}{l}\text { (1) address market failure, (2) counteract the financial crisis, (3) reporting } \\
\text { obligations, (4) decision-making constraints, (5) short, } 4-5 \text { years legislature with } \\
\text { unknown outcome of upcoming elections, (6) membership feels uneasy due to } \\
\text { constraints and volatility }\end{array}$ & Case 4 , case 3 \\
\hline 2 & Neutrality & Funding sources & $\begin{array}{l}\text { (1) mix of funding sources to diversify risk and avoid dependence, (2) dependence } \\
\text { on single source of funding, (3) organisations legal entity entitles for public } \\
\text { funding, (4) ensure sustainment of business operations via ownership }\end{array}$ & Case 4 \\
\hline 3 & Neutrality & Objectivity & $\begin{array}{l}\text { (1) board members beyond membership, (2) board members based on required } \\
\text { skills and experience, (3) independent board, (4) lack of objectivity in strategic }\end{array}$ & $\begin{array}{l}\text { Case } 3 \text {, case } 4 \text {, case } \\
1 \text {, case } 2\end{array}$ \\
\hline
\end{tabular}

(1) active project facilitation after change in programme management
(1) phase out of initial public funding, (2) self-sustainment of business operations

(1) changes in governance structure, (2) personnel changes in programme management, (3) personnel changes in steering committee

(1) evolving to private, not-for-profit organisation

(1) shifting focus away from development and demonstration towards deployment

(1) desire to shift from knowledge generation to knowledge dissemination*

(1) critically questioning status quo, (2) reassessing initial objectives and focus

(1) (desire to) shift to an active application of existing knowledge

(1) shifting from presenting status quo of technology to actively advising decision maker, (2) shifting from knowledge sharing to knowledge application via advocating

(1) desire to shift from knowledge generation to knowledge application via
operating demonstration facilities*

(1) evaluation shift from knowledge generation to business creation

(1) desire to evolve from funding provider to funding broker*

(1) planned relaunch of online platform to gain better traction to educate about technology*

Case Reference

Case 3 , case 4 , case $1 *$

Case 4

Case $1^{*}$

Case 1

Case 3 , case $4 *$

Case 3

Case $4^{*}$

Case 1

Case 1

Case 1*

Case $1^{*}$

Case 1

skills and experience, (3) independent board, (4) lack of objectivity in strategic

1 , case 2 
decision making, (5) potential conflict of personal interests, (6) evidence-based decision making, (7) external experts advise governance structure, (8) narrow technology focus, (09) loosing big picture, (10) inability to advocate

$4 \quad$ Neutrality $\quad$ Top-down change

(1) requirement to operate on a timescale as near-term as possible in a field of Case 1 technology with long development times, (2) top-down introduction of new success metrics, (3) multiple changes in parallel: strategic focus, success metrics, governance; (4) de-prioritisation of governance re-structure, (5) fluctuation of personnel, (6) unclear role of external consultants

\begin{tabular}{|c|c|c|c|c|}
\hline 5 & $\begin{array}{l}\text { Technological } \\
\text { context }\end{array}$ & Proximity to technology & (1) hands-on interaction with technology & Case 2 \\
\hline 6 & $\begin{array}{l}\text { Technological } \\
\text { context }\end{array}$ & Technology potential & $\begin{array}{l}\text { (1) keeping key industries in Europe, (2) turning a waste into a resource, (3) } \\
\text { international agreements favour technology }\end{array}$ & Case 1 , case 3 \\
\hline 7 & $\begin{array}{l}\text { Technological } \\
\text { context }\end{array}$ & Functioning markets & (1) need for demand, (2) suitable products, (3) and acceptance & Case 1 \\
\hline 8 & $\begin{array}{l}\text { Technological } \\
\text { context }\end{array}$ & Policy support & $\begin{array}{l}\text { (1) ETS not in favour of technology, (2) dependency on prices, (3) room for } \\
\text { interpretation in national implementation, (4) coordination between } \\
\text { funders/initiators to avoid redundancies, (5) effective integration of executive } \\
\text { authorities }\end{array}$ & Case 1 , case 3 \\
\hline 9 & $\begin{array}{l}\text { Technological } \\
\text { context }\end{array}$ & Technology development & $\begin{array}{l}\text { (1) high project failure rates, (2) no buy-in of industry, (3) lack of success stories, } \\
\text { (4) long technology development times ( } 5+\text { years) }\end{array}$ & Case 2 \\
\hline 10 & Shared consensus & Multi-stakeholder relationship & $\begin{array}{l}\text { (1) lack of government representation in triple helix approach, (2) collaboration of } \\
\text { policy, technology, and market is key }\end{array}$ & Case 1 , case 2 \\
\hline 11 & Shared consensus & Buy-in of partner & $\begin{array}{l}\text { (1) lack of a shared vision, (2) inability to create team spirit, (3) transactional rather } \\
\text { than impact relationship, (4) individuals in a team are key, (5) partner assembly to } \\
\text { bring community together, (6) release members from liability during capital- } \\
\text { intensive projects }\end{array}$ & Case 1 , case 4 \\
\hline 12 & Shared consensus & Partner alignment & $\begin{array}{l}\text { (1) inability to group and apply for external funding, (2) partner objectives and } \\
\text { goals diverge, (3) long alignment processes, (4) partner workshop to set technology } \\
\text { focus }\end{array}$ & Case 1 \\
\hline 13 & Shared consensus & Partner mix & $\begin{array}{l}\text { (1) mix of partner limits (introduced) evolution, (2) narrow membership leads to } \\
\text { inability to adequately represent opinion }\end{array}$ & Case 1 \\
\hline 14 & Shared consensus & Expectation management & $\begin{array}{l}\text { (1) unclear contribution of intermediary and its partners, (2) partners do not take } \\
\text { part in exploitation of technology, (3) partner expect ongoing funding (unfulfilled), } \\
\text { (4) partner expectations diverge }\end{array}$ & Case 1 \\
\hline 15 & $\begin{array}{l}\text { Internal } \\
\text { creation }\end{array}$ & Size of funding & $\begin{array}{l}\text { (1) discrepancy in available funding supply and R\&D demand, (2) lack of funding } \\
\text { to incentives new partners }\end{array}$ & Case 1 \\
\hline 16 & $\begin{array}{l}\text { Internal } \\
\text { creation }\end{array}$ & Vertical integration & $\begin{array}{l}\text { (1) capture more value by operating research/demonstration outcomes/facilities in } \\
\text { the future, (2) advocate by applying generated knowledge }\end{array}$ & Case 4 , case 3 \\
\hline
\end{tabular}




\begin{tabular}{|c|c|c|c|c|c|}
\hline 17 & $\begin{array}{l}\text { Internal } \\
\text { creation }\end{array}$ & value & $\begin{array}{l}\text { Complementary activities and } \\
\text { relationships }\end{array}$ & $\begin{array}{l}\text { (1) complementing close relationship to another intermediary, (2) interdependency } \\
\text { of early and late stage intermediation, (3) existing knowledge network, (4) desire } \\
\text { to collaborate alongside the value chain to complement competencies, (3) reach } \\
\text { out to various actors in the technology field to acquire new partners }\end{array}$ & $\begin{array}{l}\text { Case } 4 \text {, case } 2 \text {, case } \\
3 \text {, case } 1\end{array}$ \\
\hline 18 & $\begin{array}{l}\text { Internal } \\
\text { creation }\end{array}$ & value & Competencies and knowledge & $\begin{array}{l}\text { (1) pre-determination of organisation's or initiative's niche/scope by existing } \\
\text { competencies, (2) lack of understanding of technology (potential), processes, and } \\
\text { industry, (3) underdevelopment of methodologies to access technologies, (4) lack } \\
\text { of policy understanding for advocacy }\end{array}$ & Case 1 , case 2 \\
\hline 19 & $\begin{array}{l}\text { Internal } \\
\text { creation }\end{array}$ & value & Leadership & $\begin{array}{l}\text { (1) technical and market background enables to lead, (2) combination of scientific } \\
\text { and industry perspective enables leadership, (3) leadership is key }\end{array}$ & $\begin{array}{l}\text { Case } 2 \text {, case } 1 \text {, case } \\
4\end{array}$ \\
\hline 20 & $\begin{array}{l}\text { Internal } \\
\text { creation }\end{array}$ & value & $\begin{array}{l}\text { (Self-)organisation } \\
\text { management }\end{array}$ & $\begin{array}{l}\text { (1) failed to become a thought leader, (2) lack of self-organisation to secure } \\
\text { external/additional funding, (3) untapped potential to use/share one partner's } \\
\text { existing infrastructure, (4) ongoing strategic (re-)alignment leaves little room for } \\
\text { (bottom-up) decision making on the organisation's level, (5) difficulties in } \\
\text { operationalising synergetic effects between projects, (6) need to showcase that new } \\
\text { KPIs are met at the expense of ongoing knowledge generation, }\end{array}$ & Case 1 \\
\hline 21 & $\begin{array}{l}\text { Internal } \\
\text { creation }\end{array}$ & value & Exploitation management & $\begin{array}{l}\text { (1) lack of product manager/developer in or initiative, (2) lack of time to exploit } \\
\text { project outcomes, ( } 3 \text { ) no formal technology transfer, (4) lack of self-sustaining } \\
\text { business models, (5) IP with partners not intermediary, (6) openness of innovation } \\
\text { is limited by partners' attitude towards competition }\end{array}$ & Case 1 \\
\hline 22 & $\begin{array}{l}\text { Internal } \\
\text { creation }\end{array}$ & value & Enlightenment & $\begin{array}{l}\text { (1) create awareness and educate to overcome fear, (2) education is key, (3) lack } \\
\text { of industry-wide standards to understand effectiveness of technology for decision } \\
\text { making }\end{array}$ & Case 1 , case 4 \\
\hline 23 & $\begin{array}{l}\text { Internal } \\
\text { creation }\end{array}$ & value & $\begin{array}{l}\text { Communication } \\
\text { involvement }\end{array}$ & $\begin{array}{l}\text { (1) communicate to non-technical budget owner to increase understanding about } \\
\text { technology, (2) involvement of end customer, (3) lack of external communication } \\
\text { and traction of communication channels, (4) identifying partners to sustain project } \\
\text { outcomes, (5) lack of policy interaction, (6) underperformance of actionable } \\
\text { recommendation }\end{array}$ & Case 1 \\
\hline & \multicolumn{3}{|c|}{ intended/planned } & & \\
\hline
\end{tabular}




\section{Highlights}

- We studied intermediaries in carbon capture and utilisation technology development.

- We studied intermediary cases across Europe, the USA and Australia.

- The temporal aspect of innovation intermediaries is studied.

- Four survival factors essential for innovation intermediaries are synthesized. 